\title{
Late Quaternary calcium carbonate sedimentation and terrigenous input along the east Greenland continental margin
}

\author{
K.-H. Baumann ${ }^{\mathrm{a}}$, K.S. Lackschewitz ${ }^{\mathrm{a}}$, H. Erlenkeuser ${ }^{\mathrm{b}}$, R. Henrich ${ }^{\mathrm{a}}$ and B. Jünger ${ }^{\mathrm{a}}$ \\ ${ }^{a}$ GEOMAR, Research Center for Marine Geosciences, Wischhofstraße 1-3, D-2300 Kiel 14, Germany \\ ${ }^{\mathrm{b}}$ Institute for Nuclear Physics, $C^{\mathbf{1 4}}$-Laboratory, Kiel University, Leibnitzstraße 19, D-2300 Kiel 1, Germany
}

(Received November 2, 1992; revision accepted May 28, 1993)

\begin{abstract}
Baumann, K.-H., Lackschewitz, K.S., Erlenkeuser, H., Henrich, R. and Jünger, B., 1993. Late Quaternary calcium carbonate sedimentation and terrigenous input along the east Greenland continental margin. Mar. Geol., 114: 13-36.

Nine large box cores collected in the western Greenland-Iceland-Norwegian (GIN) Sea were analyzed for calcium carbonate content and coarse fraction components. Stratigraphic control is based on oxygen isotope records performed on four of the cores. All cores were correlated using oxygen and carbon isotope data, fluctuations in calcium carbonate content, coarse terrigenous particle content and volcanic ash beds.

Glacial and interglacial cycles are documented by a number of terrigenous particle events and differentiated calcium carbonate production which can be correlated to major paleoceanographic and paleoclimatic shifts. In the older core sections, extensive deposition of ice-rafted detritus (IRD) persisted until about oxygen isotope stage 9 and document a relatively stable environment in this area, strongly influenced by cold surface water masses. The following interval was characterized by variations in the general surface water circulation pattern, although high amounts of IRD are still present in Iceland Sea sediments. Pronounced shif ts in terrigenous input and pelagic carbonate records were identified close to the oxygen isotope stage $9 / 8$ and $6 / 5$ boundaries, indicating massive melting of icebergs in the western GIN Sea. These enormous inputs of debris were followed by an increase in calcium carbonate production caused by maximum intrusion of warm Atlantic surface waters. Relatively high calcium carbonate contents also show that only little dilution by fine-grained material and a minimum of ice melting occurred during these warm phases.

During oxygen isotope stage 5, conditions were more uniform indicating a less pronounced westward penetration of Atlantic waters as compared to the Holocene. The last glacial (stages 4-2) is characterized by the occurrence of "Heinrich"-like events, although high IRD contents were present throughout this interval. A distinct contrast between the northernmost cores and the cores in the south is indicative of a rather strong westward penetration of Atlantic water in the north and of an area dominated by cold water east of the Kolbeinsey Ridge during the Holocene. However, conditions west of Jan Mayen seem to have remained constantly dominated by cold surface waters throughout the whole time investigated.
\end{abstract}

\section{Introduction}

Some of the striking features of the earth's climate during the Quaternary are the dramatic deglaciations which occurred roughly every 100,000 years. Deep-sea sediments have been used as recorders of climatic changes associated with these late Pleistocene climatic cycles for many decades now. Many paleoclimatic and paleoceanographic studies in the world oceans have provided well documented changes in gross parameters such as the $\mathrm{CaCO}_{3}$ content. In the Greenland-IcelandNorwegian (GIN) Sea most of these investigations focused on the Norwegian Sea and the eastern Iceland Sea. Today the eastern GIN Sea margins are relatively ice-free due to the Norwegian Current, a relatively warm $\left(6^{\circ}-10^{\circ} \mathrm{C}\right)$, saline (35.1-35.3\%) branch of the North Atlantic Drift which flows northward on the eastern side of the basin (e.g., Swift, 1986). This is an area of longstanding geological interest and has been studied extensively (e.g., Holtedahl, 1959; Kellogg, 1976, 1980; Jansen et al., 1983; Jansen and Bjørklund, 1985; Henrich et al., 1989; Koç Karpuz and Jansen, 1992; Baumann and Matthiessen, 1992).

Deep-sea sedimentary records from the 
Norwegian Sea reflect glacial-interglacial variations and changes in ocean circulation patterns. Calcium carbonate content, oxygen isotopes, and coarse fraction components have proved to be well suited to trace and reveal major paleoceanographic and paleoclimatic changes (Kellogg, 1975, 1976; Henrich et al., 1989; Ramm, 1989; Kassens, 1990; Vogelsang, 1990). Accordingly, high calcium carbonate contents in GIN Sea sediments indicate high biogenic productivity due to the inflow of warm Atlantic surface water masses. Layers rich of terrigenous particles are interpreted to be released during the melting of huge ice masses (Heinrich, 1988; Henrich, 1990; Broecker et al., 1992). In addition, ice-rafted debris in glacialmarine sediments, which were transported either by sea ice or drifting icebergs, seems to be an important tool to gain information on the direction of surface currents and sea ice cover during late Quaternary (Bischof, 1990; Henrich, 1990; Spielhagen, 1991).

The western Iceland Sea (Lackschewitz, 1991; Stein et al., 1993) and particularly the Greenland Sea (Kellogg, 1975, 1976) have only scarcely been studied. Such a situation is especially anomalous given the potential of the deep-sea sedimentary record in this area to show important aspects of the paleoclimatic and paleoceanographic development of the past $350 \mathrm{kyr}$.

The modern surface current system in the area studied is characterized by the East Greenland Current which carries the cold $\left(<0^{\circ} \mathrm{C}\right)$, less-saline (30-34\%) polar water southward along the East Greenland shelf (Fig. 1). Between the domains of the Polar and the Atlantic waters (Norwegian Atlantic Current), the so-called Arctic Surface Water $\left(0^{\circ}-4^{\circ} \mathrm{C}, 34.6-34.9 \%\right)$ forms as a mixture of both sources. The Arctic surface water is contained in two cyclonic currents, e.g., Jan Mayen Current and East Iceland Current, fed by Polar and Atlantic waters. The system of warm and cold currents results in distinctive oceanographic fronts (Johannessen, 1986). This region is important for the climatic development because of its variable extent of the sea-ice cover, which may induce a switch between different climatic states, and because of the formation of deep water masses which fill large parts of the world ocean.
In this paper, observed changes are documented in order

- to provide basic sedimentological proxy data, e.g., calcium carbonate and terrigenous particle contents, along a $\mathrm{N}-\mathrm{S}$ transect of well-dated sediment cores along the Greenland continental margin;

- to relate down core variations in bulk calcium carbonate content and coarse terrigenous particle values to glacial/interglacial changes in the surface water regime at the western margin of the GIN Sea;

- to display the occurrence of specific IRD tracers in the sediments and to discuss their significance for paleoceanographic reconstructions.

\section{Material and methods}

Most of the material studied comprises of cores recovered during R.V. Polarstern Cruise ARK VII/1 (Thiede and Hempel, 1991). The cores were collected along a $\mathrm{S}-\mathrm{N}$ transect from the Kolbeinsey Ridge area to the Greenland Fracture Zone (Fig. 2). Three sediment cores taken during Meteor Cruise 7/5 (Hirschleber et al., 1988) and Polarstern Cruise ARK VI/2 (Krause et al., 1991) were analyzed in order to complete the transect. The core locations and bulk data of the surface sediments are presented in Table 1a. In addition, calcium carbonate data of surface samples were taken from Kellogg (1975) and listed in Table $1 \mathrm{~b}$.

\section{Determination of bulk calcium carbonate}

Calcium carbonate content was measured using two different methods. Carbonate bomb measurements (Müller and Gastner, 1971) were directly carried out aboard the R.V. Polarstern during cruise ARK VII/1. The amount of carbonate was determined by the $\mathrm{CO}_{2}$-pressure in a known volume after treating the sample with $\mathrm{HCl}$. Calibration was achieved using pure $\mathrm{CaCO}_{3}$. Analytical precision from replicate analyses can be given better than $\pm<1 \mathrm{wt} . \% \mathrm{CaCO}_{3}$ on the average.

In addition, a LECO CS-125 infrared analyzer was used for bulk calcium carbonate measurements. Both total carbon (TC) and total organic carbon (TOC) were determined by infrared absorp- 


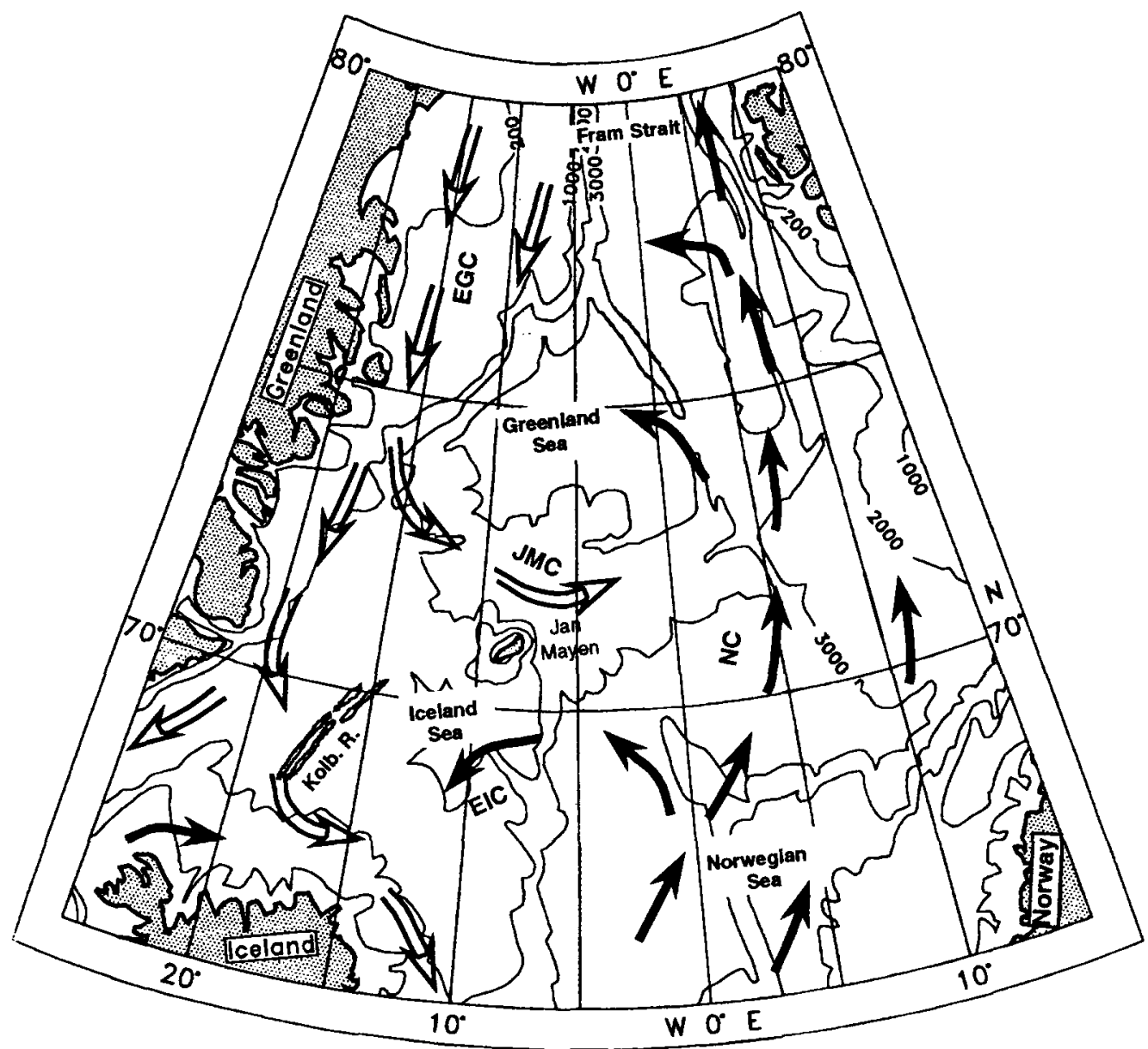

Fig. 1. Major surface circulation pattern in the GIN Sea $(K o l b . R .=$ Kolbeinsey Ridge; $E G C=$ East Greenland Current; $N C=$ Norwegian Current; $E I C=$ East Iceland Current; $J M C=$ Jan Mayen Current).

tion of $\mathrm{CO}_{2}$ produced by thermal decomposition of the sample. Organic carbon was calculated from $\mathrm{CO}_{2}$ that was released by treatment with hydrochloric acid. The calcium carbonate content was calculated as weight percent of the bulk sample as:

$\mathrm{CaCO}_{3} \%=(\mathrm{TC} \%-\mathrm{TOC} \%) \times 8.3$

\section{Coarse fraction analysis}

Samples taken usually at $5 \mathrm{~cm}$ or $10 \mathrm{~cm}$ intervals were analyzed for the composition of their coarse fraction. The sediment samples were dried, weighed and washed on $63 \mu \mathrm{m}$ sieve. The coarse fraction was further split into $63-125 \mu \mathrm{m}, 125-250 \mu \mathrm{m}$, $250-500 \mu \mathrm{m}$, and $>500 \mu \mathrm{m}$ subfractions. The particle association of the $125-500 \mu \mathrm{m}$ fraction seems to be most representative for coarse fraction composition with respect to biogenic calcium carbonate versus terrigenous particles. Thus, a split (>500 grains) of this size fraction was studied and counted for biogenic, terrigenous and volcanic components. In addition, some samples were investigated in detail for abundances of coccoliths, using a scanning electron microscope.

\section{Stratigraphy and accumulation rates}

Stratigraphic control is mainly based on oxygen isotope records performed on four of the cores. Some additional stratigraphic information is provided by volcanic ash beds and the carbon isotope records.

Oxygen and carbon isotope measurements have 


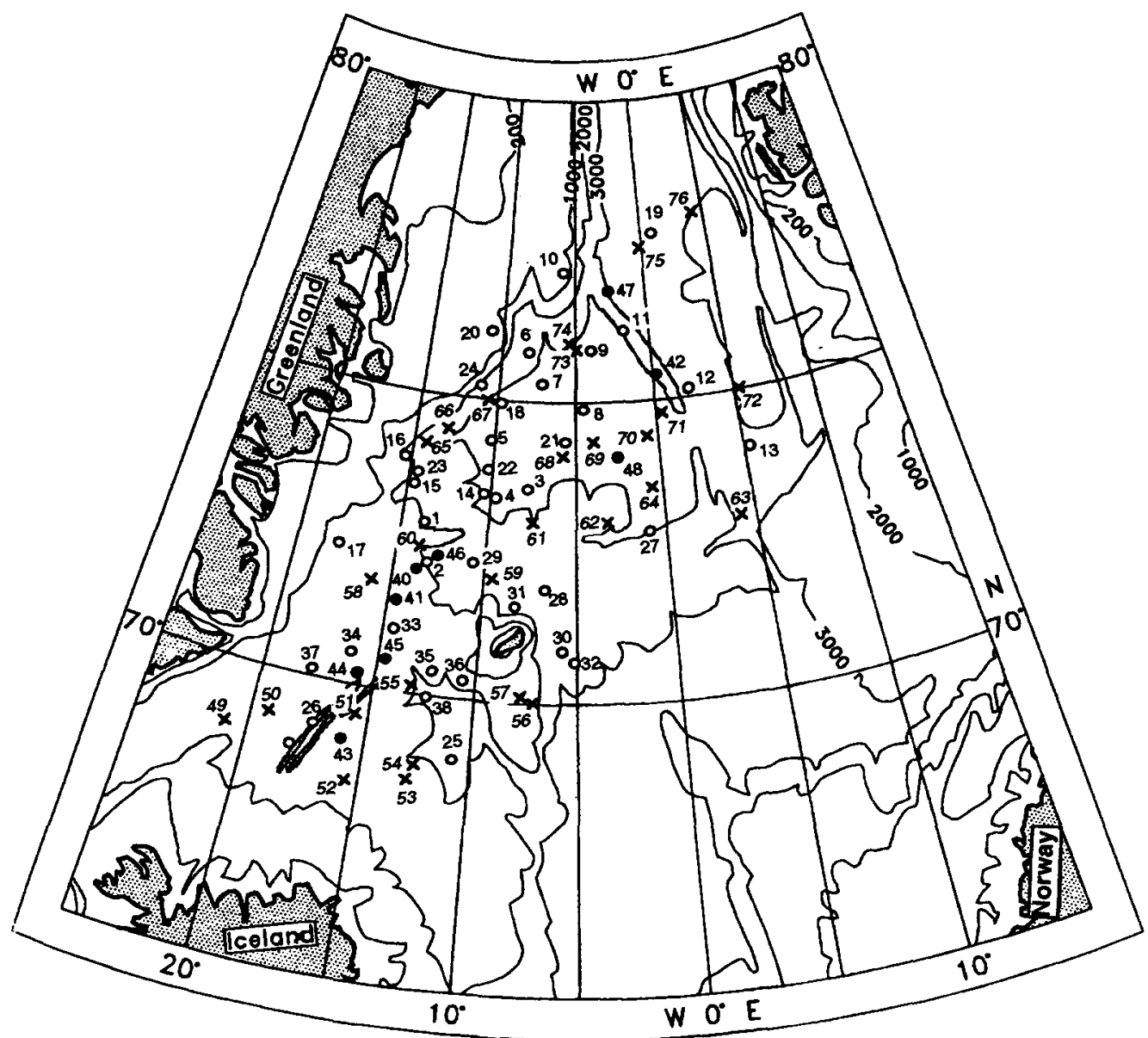

Fig. 2. Locations of surface samples $(\bigcirc)$ and cores $(\bullet)$ from this study and surface samples $(\times)$ from Kellogg (1975).

been carried out on the planktic foraminifera Neogloboquadrina pachyderma sin. (125-250 $\mu \mathrm{m}$ fraction). The measurements were performed in the $\mathrm{C}^{14}$-Laboratory at the Kiel University on a Finnigan MAT 251 mass spectrometer onlinecoupled to the automated Kiel carbonate device. Foraminiferal samples, down to $12 \mu \mathrm{g}$ of weight, were reacted with a few, freshly added drops of $100 \%$ orthophosphoric acid at $73^{\circ} \mathrm{C}$ under vacuum. Calibration to the PDB-scale is based on the NBS 20 calcite standard. Results are expressed on the usual $\delta$-notation, and total reproducibility amounts to $0.08 \%$ and $0.05 \%$ for $\delta^{18} \mathrm{O}$ and $\delta^{13} \mathrm{C}$, respectively. Isotopic events and stage boundaries in the oxygen isotope records were established according to Imbrie et al. (1984), Martinson et al.
(1987) and Vogelsang (1990), and are listed in Table 2 and indicated in Figs. 5-8. Further comprehensive correlation of the cores to each other is based on fluctuations in calcium carbonate content, the pattern of terrigenous input and the occurrence of volcanic ash beds.

Bulk accumulation rates of calcium carbonate $\left(\mathrm{AR}_{\mathrm{CaCO}_{3}}\right)$ were calculated by using the equations given in Ehrmann and Thiede (1985):

$\mathrm{AR}_{\mathrm{BULK}}=\mathrm{LSR} \times \mathrm{DBD}$

$\mathrm{AR}_{\mathrm{CaCO}_{3}}=\mathrm{AR}_{\mathrm{BULK}} \times \mathrm{CaCO}_{3} \mathrm{wt} . \% \times 100^{-1}$

LSR $=$ linear sedimentation rate $\left(\mathrm{cm} \mathrm{kyr}^{-1}\right)$; $\mathrm{DBD}=$ dry bulk density $\left(\mathrm{g} \mathrm{cm}^{-3}\right)$. 
TABLE 1a

Position, water depth, carbonate and coarse terrigenous content (weight $\%$ ) of surface sediments and cores (indicated by ${ }^{*}$ ) studied in this investigation

\begin{tabular}{|c|c|c|c|c|c|c|c|}
\hline $\mathrm{Nr}$. & Cruise & Station & Latitude & Longitude & $\begin{array}{l}\text { Depth } \\
\text { (m) }\end{array}$ & $\begin{array}{l}\text { Bulk } \\
\text { carbonate } \\
\text { content } \\
\text { (wt. \%) }\end{array}$ & $\begin{array}{l}\text { Coarse } \\
\text { terrigenous } \\
\text { particles } \\
(\text { wt. } \% \text { ) }\end{array}$ \\
\hline 1 & ARK VII/1 & 1876 & $72^{\circ} 48.4 \mathrm{~N}$ & $12^{\circ} 46.4 \mathrm{~W}$ & 2592 & & 1.2 \\
\hline 2 & ARK VII/1 & 1877 & $72^{\circ} 28.7 \mathrm{~N}$ & $13^{\circ} 04.2 \mathrm{~W}$ & 2649 & 11.2 & \\
\hline 3 & ARK VII/1 & 1882 & $73^{\circ} 35.5 \mathrm{~N}$ & $08^{\circ} 23.8 \mathrm{~W}$ & 3169 & & 1.7 \\
\hline 4 & ARK VII/1 & 1892 & $73^{\circ} 44.0 \mathrm{~N}$ & $09^{\circ} 37.5 \mathrm{~W}$ & 3125 & 18.1 & \\
\hline 5 & ARK VII/1 & 1893 & $74^{\circ} 52.0 \mathrm{~N}$ & $10^{\circ} 06.5 \mathrm{~W}$ & 3245 & 16.7 & \\
\hline 6 & ARK VII/1 & 1894 & $75^{\circ} 48.8 \mathrm{~N}$ & $08^{\circ} 15.5 \mathrm{~W}$ & 1992 & 9.3 & 23.8 \\
\hline 7 & ARK VII/1 & 1895 & $75^{\circ} 24.8 \mathrm{~N}$ & $07^{\circ} 18.6 \mathrm{~W}$ & 3358 & 25.0 & 4.0 \\
\hline 8 & ARK VII/1 & 1898 & $74^{\circ} 59.1 \mathrm{~N}$ & $04^{\circ} 57.9 \mathrm{~W}$ & 3595 & 24.6 & 1.1 \\
\hline 9 & ARK VII/1 & 1901 & $75^{\circ} 56.6 \mathrm{~N}$ & $03^{\circ} 44.4 \mathrm{~W}$ & 3588 & 25.4 & 3.4 \\
\hline 10 & ARK VII/1 & 1902 & $77^{\circ} 25.6 \mathrm{~N}$ & $05^{\circ} 45.9 \mathrm{~W}$ & 422 & 5.9 & 42.2 \\
\hline 11 & ARK VII/1 & 1908 & $76^{\circ} 19.2 \mathrm{~N}$ & $01^{\circ} 04.3 \mathrm{~W}$ & 2497 & 14.2 & \\
\hline 12 & ARK VII/1 & 1911 & $75^{\circ} 03.5 \mathrm{~N}$ & $02^{\circ} 58.5 \mathrm{E}$ & 2326 & 34.4 & \\
\hline 13 & ARK VII/1 & 1913 & $74^{\circ} 29.1 \mathrm{~N}$ & $05^{\circ} 24.4 \mathrm{E}$ & 2857 & 36.3 & \\
\hline 14 & ARK $V / 3$ & 1697 & $73^{\circ} 45.1 \mathrm{~N}$ & $10^{\circ} 28.5 \mathrm{~W}$ & 3062 & 12.9 & \\
\hline 15 & ARK $V / 3$ & 1698 & $74^{\circ} 10.6 \mathrm{~N}$ & $14^{\circ} 34.1 \mathrm{~W}$ & 877 & 2.8 & \\
\hline 16 & ARK V/3 & 1699 & $74^{\circ} 25.6 \mathrm{~N}$ & $15^{\circ} 18.7 \mathrm{~W}$ & 311 & 2.6 & \\
\hline 17 & ARK V/3 & 1700 & $72^{\circ} 39.9 \mathrm{~N}$ & $17^{\circ} 50.4 \mathrm{~W}$ & 279 & 0.3 & \\
\hline 18 & ARK V/3 & 1702 & $74^{\circ} 59.9 \mathrm{~N}$ & $09^{\circ} 46.5 \mathrm{~W}$ & 3227 & 22.0 & 3.1 \\
\hline 19 & ARK V/3 & 1704 & $78^{\circ} 23.6 \mathrm{~N}$ & $01^{\circ} 06.1 \mathrm{E}$ & 1195 & 5.3 & \\
\hline 20 & ARK V/3 & 1705 & $75^{\circ} 42.9 \mathrm{~N}$ & $11^{\circ} 13.5 \mathrm{~W}$ & 401 & 5.7 & \\
\hline 21 & ARK V/3 & 1706 & $74^{\circ} 13.8 \mathrm{~N}$ & $10^{\circ} 02.3 \mathrm{~W}$ & 3158 & & 3.5 \\
\hline 22 & ARK VI/2 & 1736 & $74^{\circ} 19.7 \mathrm{~N}$ & $05^{\circ} 10.9 \mathrm{~W}$ & 3460 & & 1.5 \\
\hline 23 & ARK VI/2 & 1737 & $73^{\circ} 44.5 \mathrm{~N}$ & $14^{\circ} 52.8 \mathrm{~W}$ & 1760 & & 21.1 \\
\hline 24 & ARK VI/2 & 1741 & $75^{\circ} 18.4 \mathrm{~N}$ & $10^{\circ} 58.8 \mathrm{~W}$ & 2041 & & 29.2 \\
\hline 25 & ARK II $/ 4$ & 23245 & $69^{\circ} 23.0 \mathrm{~N}$ & $10^{\circ} 47.0 \mathrm{~W}$ & 1750 & & 2.4 \\
\hline 26 & ARK II $/ 4$ & 23247 & $69^{\circ} 29.5 \mathrm{~N}$ & $17^{\circ} 07.0 \mathrm{~W}$ & 1400 & & 1.7 \\
\hline 27 & M $7 / 3$ & 23270 & $73^{\circ} 10.0 \mathrm{~N}$ & $00^{\circ} 48.7 \mathrm{~W}$ & 2755 & 15.8 & \\
\hline 28 & M 7/3 & 23293 & $72^{\circ} 37.3 \mathrm{~N}$ & $06^{\circ} 35.5 \mathrm{~W}$ & 2574 & 12.3 & \\
\hline 29 & M 7/3 & 23294 & $72^{\circ} 22.0 \mathrm{~N}$ & $10^{\circ} 35.5 \mathrm{~W}$ & 2224 & 9.7 & \\
\hline 30 & M $7 / 3$ & 23295 & $71^{\circ} 09.9 \mathrm{~N}$ & $05^{\circ} 52.5 \mathrm{~W}$ & 1553 & 6.1 & 41.1 \\
\hline 31 & M $7 / 5$ & 23342 & $71^{\circ} 37.9 \mathrm{~N}$ & $08^{\circ} 24.8 \mathrm{~W}$ & 1951 & 14.1 & \\
\hline 32 & $\mathrm{M} 7 / 5$ & 23341 & $70^{\circ} 57.1 \mathrm{~N}$ & $05^{\circ} 32.6 \mathrm{~W}$ & 1735 & 24.5 & \\
\hline 33 & M 7/5 & 23346 & $71^{\circ} 17.7 \mathrm{~N}$ & $14^{\circ} 03.9 \mathrm{~W}$ & 1211 & 1.4 & \\
\hline 34 & M $7 / 5$ & 23347 & $70^{\circ} 26.5 \mathrm{~N}$ & $16^{\circ} 04.6 \mathrm{~W}$ & 1231 & & 5.2 \\
\hline 35 & M $7 / 5$ & 23353 & $70^{\circ} 34.2 \mathrm{~N}$ & $12^{\circ} 43.3 \mathrm{~W}$ & 1394 & 8.1 & \\
\hline 36 & $\mathrm{M} 7 / 5$ & 23354 & $70^{\circ} 19.9 \mathrm{~N}$ & $10^{\circ} 37.7 \mathrm{~W}$ & 1747 & 25.6 & \\
\hline 37 & M $7 / 5$ & 23351 & $70^{\circ} 21.7 \mathrm{~N}$ & $18^{\circ} 21.1 \mathrm{~W}$ & 1679 & & 6.9 \\
\hline 38 & $\mathbf{M} 7 / 5$ & 23352 & $70^{\circ} 00.4 \mathrm{~N}$ & $12^{\circ} 25.8 \mathrm{~W}$ & 1819 & 42.8 & \\
\hline 39 & Pos $158 / 1$ & $0004 / 1$ & $68^{\circ} 48.2 \mathrm{~N}$ & $17^{\circ} 42.6 \mathrm{~W}$ & 1481 & 7.2 & \\
\hline $40^{*}$ & $\mathbf{M} 7 / 5$ & 23343 & $72^{\circ} 12.9 \mathrm{~N}$ & $13^{\circ} 00.3 \mathrm{~W}$ & 2391 & 9.9 & \\
\hline $41^{*}$ & M 7/5 & 23345 & $71^{\circ} 40.2 \mathrm{~N}$ & $14^{\circ} 18.5 \mathrm{~W}$ & 1369 & 2.4 & 2.7 \\
\hline $42^{*}$ & ARK VI/2 & 1748 & $75^{\circ} 31.4 \mathrm{~N}$ & $00^{\circ} 49.5 \mathrm{E}$ & 1730 & 28.5 & \\
\hline $43^{*}$ & ARK VII/1 & 1845 & $69^{\circ} 27.6 \mathrm{~N}$ & $15^{\circ} 45.3 \mathrm{~W}$ & 922 & 17.7 & \\
\hline $44^{*}$ & ARK VII/1 & 1852 & $70^{\circ} 15.7 \mathrm{~N}$ & $15^{\circ} 49.8 \mathrm{~W}$ & 1117 & 6.0 & \\
\hline $45^{*}$ & ARK VII/1 & 1857 & $70^{\circ} 28.8 \mathrm{~N}$ & $14^{\circ} 30.4 \mathrm{~W}$ & 901 & 6.1 & \\
\hline $46^{*}$ & ARK VII/1 & 1875 & $72^{\circ} 32.9 \mathrm{~N}$ & $12^{\circ} 14.1 \mathrm{~W}$ & 2366 & 11.0 & \\
\hline $47^{*}$ & ARK VII/1 & 1906 & $76^{\circ} 50.2 \mathrm{~N}$ & $02^{\circ} 09.2 \mathrm{~W}$ & 2939 & 16.0 & \\
\hline $48^{*}$ & ARK VII/1 & 1900 & $74^{\circ} 12.9 \mathrm{~N}$ & $02^{\circ} 19.7 \mathrm{~W}$ & 3546 & 15.0 & 0.6 \\
\hline
\end{tabular}


TABLE $1 b$

Location, water depth and carbonate content (weight $\%$ ) for additional surface samples used in this study (from Kellogg, 1975)

\begin{tabular}{llll}
\hline Nr. Core no. Latitude & Longitude & $\begin{array}{l}\text { Depth } \\
(\mathrm{m})\end{array}$ & $\begin{array}{l}\text { Bulk } \\
\text { carbonate } \\
\text { wt. \% }\end{array}$ \\
\hline
\end{tabular}

\begin{tabular}{|c|c|c|c|c|c|}
\hline 49 & V 28-18 & $68^{\circ} 47.0 \mathrm{~N}$ & $20^{\circ} 46.0 \mathrm{~W}$ & 1326 & 0.7 \\
\hline 50 & V 29-207 & $69^{\circ} 15.7 \mathrm{~N}$ & $19^{\circ} 30.5 \mathrm{~W}$ & 1461 & 3.8 \\
\hline 51 & V $27-48$ & $69^{\circ} 26.3 \mathrm{~N}$ & $15^{\circ} 53.9 \mathrm{~W}$ & 1017 & 2.3 \\
\hline 52 & V 28-19 & $68^{\circ} 13.0 \mathrm{~N}$ & $15^{\circ} 16.0 \mathrm{~W}$ & 1374 & 12.8 \\
\hline 53 & V 27-47 & $68^{\circ} 27.7 \mathrm{~N}$ & $13^{\circ} 32.5 \mathrm{~W}$ & 1717 & 37.9 \\
\hline 54 & V 28-36 & $68^{\circ} 43.0 \mathrm{~N}$ & $12^{\circ} 43.0 \mathrm{~W}$ & 1816 & 48.0 \\
\hline 55 & V 27-49 & $70^{\circ} 14.9 \mathrm{~N}$ & $13^{\circ} 04.0 \mathrm{~W}$ & 1392 & 15.4 \\
\hline 56 & V 29-212 & $70^{\circ} 09.0 \mathrm{~N}$ & $07^{\circ} 20.7 \mathrm{~W}$ & 1447 & 15.5 \\
\hline 57 & V 27-51 & $70^{\circ} 23.6 \mathrm{~N}$ & $07^{\circ} 47.1 \mathrm{~W}$ & 950 & 10.0 \\
\hline 58 & V 28-21 & $71^{\circ} 46.0 \mathrm{~N}$ & $15^{\circ} 30.0 \mathrm{~W}$ & 971 & 1.5 \\
\hline 59 & V 28-37 & $72^{\circ} 04.0 \mathrm{~N}$ & $09^{\circ} 04.0 \mathrm{~W}$ & 2395 & 11.2 \\
\hline 60 & V 28-22 & $72^{\circ} 26.0 \mathrm{~N}$ & $13^{\circ} 39.0 \mathrm{~W}$ & 1284 & 8.0 \\
\hline 61 & V 29-214 & $72^{\circ} 58.1 \mathrm{~N}$ & $06^{\circ} 59.4 \mathrm{~W}$ & 2600 & 15.6 \\
\hline 62 & V 27-54 & $73^{\circ} 06.5 \mathrm{~N}$ & $03^{\circ} 42.7 \mathrm{~W}$ & 2834 & 12.4 \\
\hline 63 & V 27-59 & $73^{\circ} 04.2 \mathrm{~N}$ & $04^{\circ} 49.2 \mathrm{E}$ & 2299 & 46.7 \\
\hline 64 & V 28-28 & $73^{\circ} 29.0 \mathrm{~N}$ & $00^{\circ} 50.0 \mathrm{~W}$ & 2288 & 21.2 \\
\hline 65 & V 29-213 & $74^{\circ} 21.2 \mathrm{~N}$ & $14^{\circ} 22.1 \mathrm{~W}$ & 466 & 6.1 \\
\hline 66 & V $28-23$ & $74^{\circ} 31.0 \mathrm{~N}$ & $13^{\circ} 07.0 \mathrm{~W}$ & 2325 & 10.1 \\
\hline 67 & V 27.82 & $74^{\circ} 59.6 \mathrm{~N}$ & $10^{\circ} 48.4 \mathrm{~W}$ & 2895 & 29.6 \\
\hline 68 & V $27-83$ & $74^{\circ} 11.6 \mathrm{~N}$ & $05^{\circ} 42.9 \mathrm{~W}$ & 3416 & 25.1 \\
\hline 69 & V $27-55$ & $74^{\circ} 29.7 \mathrm{~N}$ & $04^{\circ} 39.4 \mathrm{~W}$ & 3519 & 24.6 \\
\hline 70 & V $27-57$ & $74^{\circ} 27.9 \mathrm{~N}$ & $01^{\circ} 11.4 \mathrm{~W}$ & 3605 & 14.9 \\
\hline 71 & V 23-62 & $74^{\circ} 54.0 \mathrm{~N}$ & $01^{\circ} 36.5 \mathrm{E}$ & 3713 & 32.4 \\
\hline 72 & V 27-78 & $75^{\circ} 17.7 \mathrm{~N}$ & $05^{\circ} 56.5 \mathrm{E}$ & 2765 & 44.7 \\
\hline 73 & V $29-215$ & $75^{\circ} 55.5 \mathrm{~N}$ & $05^{\circ} 07.0 \mathrm{~W}$ & 3118 & 32.9 \\
\hline 74 & V $27-56$ & $76^{\circ} 09.5 \mathrm{~N}$ & $05^{\circ} 23.9 \mathrm{~W}$ & 2736 & 27.0 \\
\hline 75 & V 23-63 & $77^{\circ} 57.4 \mathrm{~N}$ & $00^{\circ} 12.2 \mathrm{E}$ & 3050 & 11.5 \\
\hline 76 & V $27-75$ & $78^{\circ} 16.4 \mathrm{~N}$ & $04^{\circ} 26.4 \mathrm{E}$ & 2412 & 15.2 \\
\hline
\end{tabular}

The determination of the dry bulk density were outlined by Holler and Kassens (1989).

\section{Results}

\section{Distribution of calcium carbonate in surface sediments}

Calcium carbonate contents in surface sediments reach highest values (>30 wt.\%) in the eastern and southeastern parts of the central GIN Sea (Fig. 3). Towards the Greenland continental margin, a general decrease in calcium carbonate content was observed. Relatively high calcium carbonate values (e.g., $>20$ wt. $\% \mathrm{CaCO}_{3}$ ) still exist in two tongue-shaped sectors, where branches of the Norwegian Atlantic Current enter the Iceland and the Greenland Sea (see Fig. 1). In contrast, very low carbonate values (generally $<10 \mathrm{wt} . \% \mathrm{CaCO}_{3}$ ) were measured around and west of Jan Mayen, indicating a low calcium carbonate shell production within the cold surface water masses of the Jan Mayen Current. Sediments underlying the cold East Greenland Current in the western GIN Sea and the East Greenland continental margin are characterized by the lowest calcium carbonate values $(<5 \mathrm{wt} . \%)$. Generally, these results are in good agreement with previously published data (Kellogg, 1975, 1976; Paetsch et al., 1992). 
TABLE 2

Age-depth relations of isotopically dated cores $(\mathrm{Im}=\mathrm{Imbrie}$ et al., 1984; $\mathrm{Ma}=$ Martinson et al., 1987; Vo= Vogelsang, 1990)

\begin{tabular}{|c|c|c|c|c|c|c|}
\hline \multirow{2}{*}{$\begin{array}{l}\text { Stage } \\
\text { boundaries, } \\
\text { events }\end{array}$} & \multirow{2}{*}{$\begin{array}{l}\text { Source of } \\
\text { data point }\end{array}$} & \multirow{2}{*}{$\begin{array}{l}\text { Age } \\
(y r)\end{array}$} & \multicolumn{4}{|c|}{ Depth $(\mathrm{cm})$ in } \\
\hline & & & core 1845 & core 1852 & core 1900 & core 1906 \\
\hline 1.1 & Vo & 8,600 & & 10 & & 5.5 \\
\hline $1 / 2$ & $\mathrm{Ma}$ & 12,000 & 28 & & 21 & 24 \\
\hline 2.2 & $\mathrm{Ma}$ & 18,200 & 51 & & 29 & 40.5 \\
\hline $2 / 3$ & $\mathrm{Ma}$ & 24,110 & 81 & & 60 & \\
\hline 3.1 & $\mathrm{Ma}$ & 25,420 & 91 & & 67 & 45.5 \\
\hline 3.3 & $\mathrm{Ma}$ & 50,210 & 141 & 178 & 122 & 160.5 \\
\hline $3 / 4$ & $\mathrm{Im}$ & 59,000 & 151 & 208 & 125 & 162 \\
\hline 4.2 & $\mathrm{Ma}$ & 64,090 & 161 & 218 & 127 & 170.5 \\
\hline $4 / 5$ & $\operatorname{Im}$ & 71,000 & 171 & 228 & 140 & 173 \\
\hline 5.1 & $\mathrm{Ma}$ & 79,250 & & 238 & 142 & 175.5 \\
\hline 5.2 & $\mathrm{Ma}$ & 90,950 & & 248 & & 185.5 \\
\hline 5.3 & $\mathrm{Ma}$ & 99,380 & & 258 & & 190.5 \\
\hline 5.4 & $\mathrm{Ma}$ & 110,790 & & 268 & & 200.5 \\
\hline 5.5 & $\mathrm{Ma}$ & 123,820 & & 278 & 180 & 215.5 \\
\hline $5 / 6$ & $\mathrm{Im}$ & 128,000 & 225 & 288 & 202 & 238 \\
\hline 6.2 & $\mathrm{Ma}$ & 135,100 & 231 & 298 & 207 & 260.5 \\
\hline 6.3 & $\mathrm{Ma}$ & 142,280 & 261 & 330 & 212 & 270.5 \\
\hline 6.4 & $\mathrm{Ma}$ & 152,580 & & 357 & 222 & 275.5 \\
\hline $6 / 7$ & Im & 186,000 & & 432 & 257 & 297 \\
\hline 7.1 & $\mathrm{Ma}$ & 193,070 & & 438 & 267 & 315.5 \\
\hline 7.2 & $\mathrm{Ma}$ & 200,570 & & 460 & 272 & 320.5 \\
\hline 7.3 & $\mathrm{Ma}$ & 215,540 & & 478 & 277 & 340.4 \\
\hline 7.4 & $\mathrm{Ma}$ & 224,890 & & 488 & 287 & 350.5 \\
\hline 7.5 & $\mathrm{Ma}$ & 240,190 & & 518 & 292 & 390.5 \\
\hline $7 / 8$ & $\operatorname{Im}$ & 245,000 & & 528 & 307 & 393 \\
\hline 8.3 & $\operatorname{Im}$ & 257,000 & & 560 & 322 & \\
\hline $8 / 9$ & Im & 303,000 & & & 330 & 457 \\
\hline 9.1 & $\operatorname{Im}$ & 310,000 & & & & 460.5 \\
\hline 9.2 & $\operatorname{Im}$ & 320,000 & & & & 465.5 \\
\hline 9.3 & $\mathrm{Im}$ & 331,000 & & & & 480.5 \\
\hline $9 / 10$ & $\mathrm{Im}$ & 339,000 & & & 375 & 482 \\
\hline 10.2 & $\operatorname{Im}$ & 341,000 & & & & 495.5 \\
\hline $10 / 11$ & $\mathrm{Im}$ & 362,000 & & & & 502 \\
\hline 11.3 & $\mathrm{Im}$ & 405,000 & & & & 560.5 \\
\hline $11 / 12$ & $\mathrm{Im}$ & 423,000 & & & & 570 \\
\hline
\end{tabular}

Distribution of coarse terrigenous components in surface sediments

The distribution of coarse terrigenous material in sediments of the GIN Sea appears to be the best indicator to trace changes in sea-ice cover, iceberg production, and ice rafting of debris. The transport of coarse grained material is mainly controlled by sediment uptake on continents and shelves by surging glaciers (Henrich, 1990).
Generally, the surface sediments of the deep Greenland Basin and the Iceland Plateau are made up of less than $10 \mathrm{wt} . \%$ coarse-sand and gravel (Fig. 4). An increase in coarse terrigenous components $(20-50 \mathrm{wt} . \%)$ was observed on the Greenland continental margin. This suggests that melting of ice (icebergs and sea-ice) increases towards the East Greenland shelf. However, high concentrations of coarse material on the shelf are also likely due to sediment winnowing. Generally, 


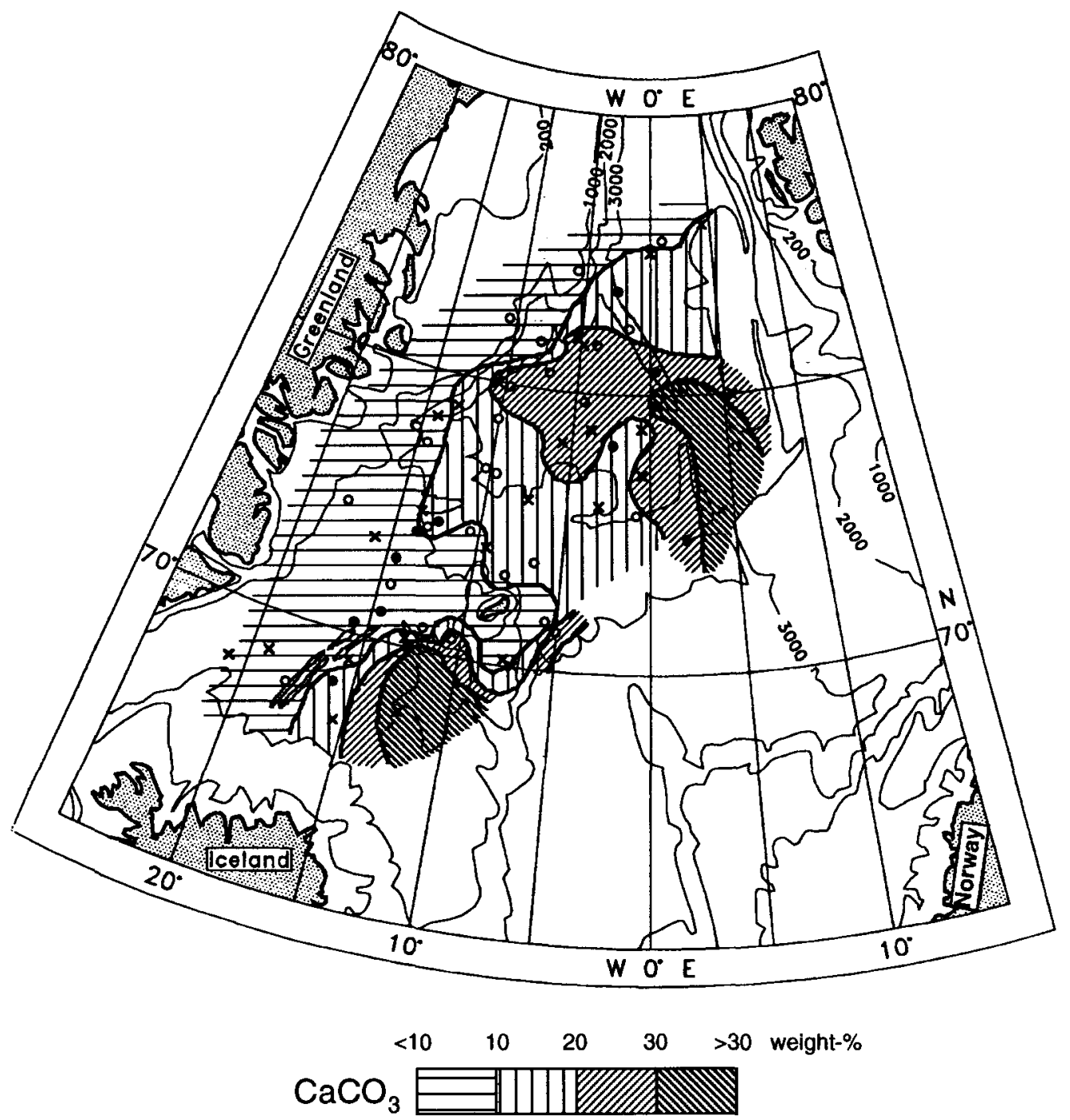

Fig. 3. Distribution of calcium carbonate content (wt.\%) in surface sediments of the western GIN Sea.

these results are in good accordance with accumulation rates of terrigenous matter in surface sediments as described by Paetsch et al. (1992).

\section{Stratigraphy and correlation of sediment cores}

Stratigraphic control is based on planktic oxygen and carbon isotope records performed on cores 1845, 1852, 1900 and 1906 (Figs. 5-8). Records of cores 1900 and 1906 reflect isotope stages $1-10$ and $1-11$, respectively. The basal age of core 1845 is not older than middle stage 6 and that of 1852 not older than early stage $8 . \delta^{18} \mathrm{O}$ values vary from
4.8 to $2.9 \%$. Although maximum values during glacial stages are relatively similar to those measured in most deep-sea records of high latitudes, some additional very light peaks were observed (e.g., core $1845,141 \mathrm{~cm}$; core $1900,122 \mathrm{~cm}$; core $1906,235,5 \mathrm{~cm}$; core $1852,440 \mathrm{~cm}$ and $568 \mathrm{~cm}$ ).

Additional stratigraphic information is provided by the $\delta^{13} \mathrm{C}$ records of $N$. pachyderma sin. The downcore carbon isotope record correlates well with the oxygen isotope curves (Figs. 5-8). The carbon isotopes follow the glacial/interglacial cycles by shifting to $\delta^{13} \mathrm{C}$-enriched values during most interglacials and to $\delta^{13} \mathrm{C}$-depleted values 


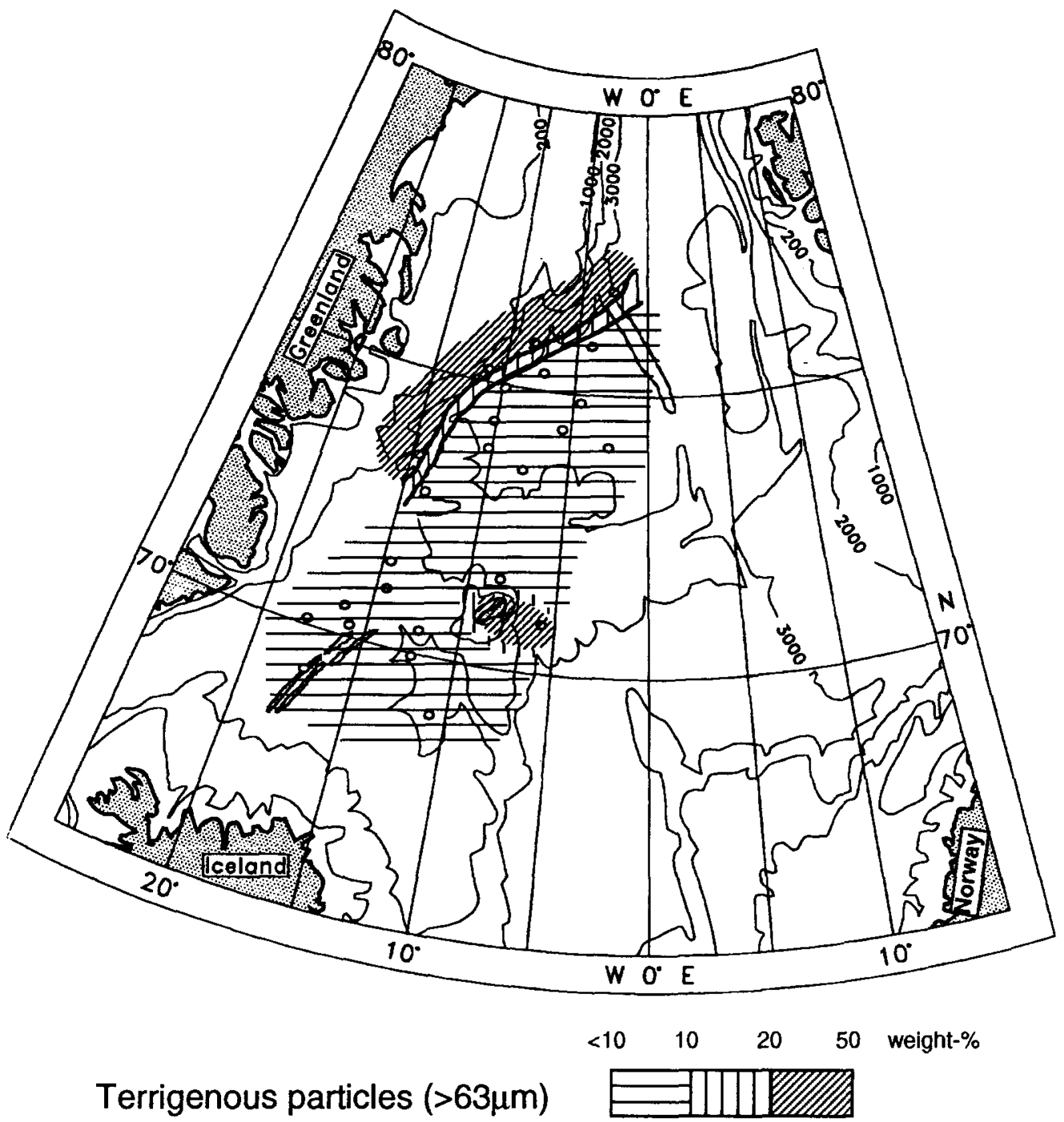

Fig. 4. Distribution of coarse terrigenous material (wt. \%) in surface samples of the western GIN Sea.

during glacial periods. This fluctuation shows differences in $\delta^{13} \mathrm{C}$ values of about 0.7 to $0.9 \%$. The $\delta^{13} \mathrm{C}$ record of core 1906 reveals a maximum isotopic shift of $1.4 \%$ during the isotope stage $6 / 5$ transition.

The oxygen isotope data of cores 1845,1852 , 1900 and 1906 serve as a framework for the stratigraphic correlation of all records. For a comprehensive correlation of all the cores down-core variations in calcium carbonate contents and terrigenous particle contents were used. Most of the isotope stage boundaries from isotope stage 9 to 1 could be distinguished on the basis of carbonate and terrigenous records. However, cores west of Jan Mayen (cores 1875, 23343 and 23345) have uniformly low calcium carbonate values and exhibit limited down-core variations, which make a precise stratigraphic correlation difficult.

A major increase in terrigenous particle supply together with a decrease in carbonate content is characteristic of sediment deposited prior to oxygen isotope stage 8 . A distinct horizon of volcanic ash is observed in cores 1852 and 1857 within oxygen isotope stage 7 . All the cores show an increase in calcium carbonate and a drastic decrease in terrigenous particles at the isotope 


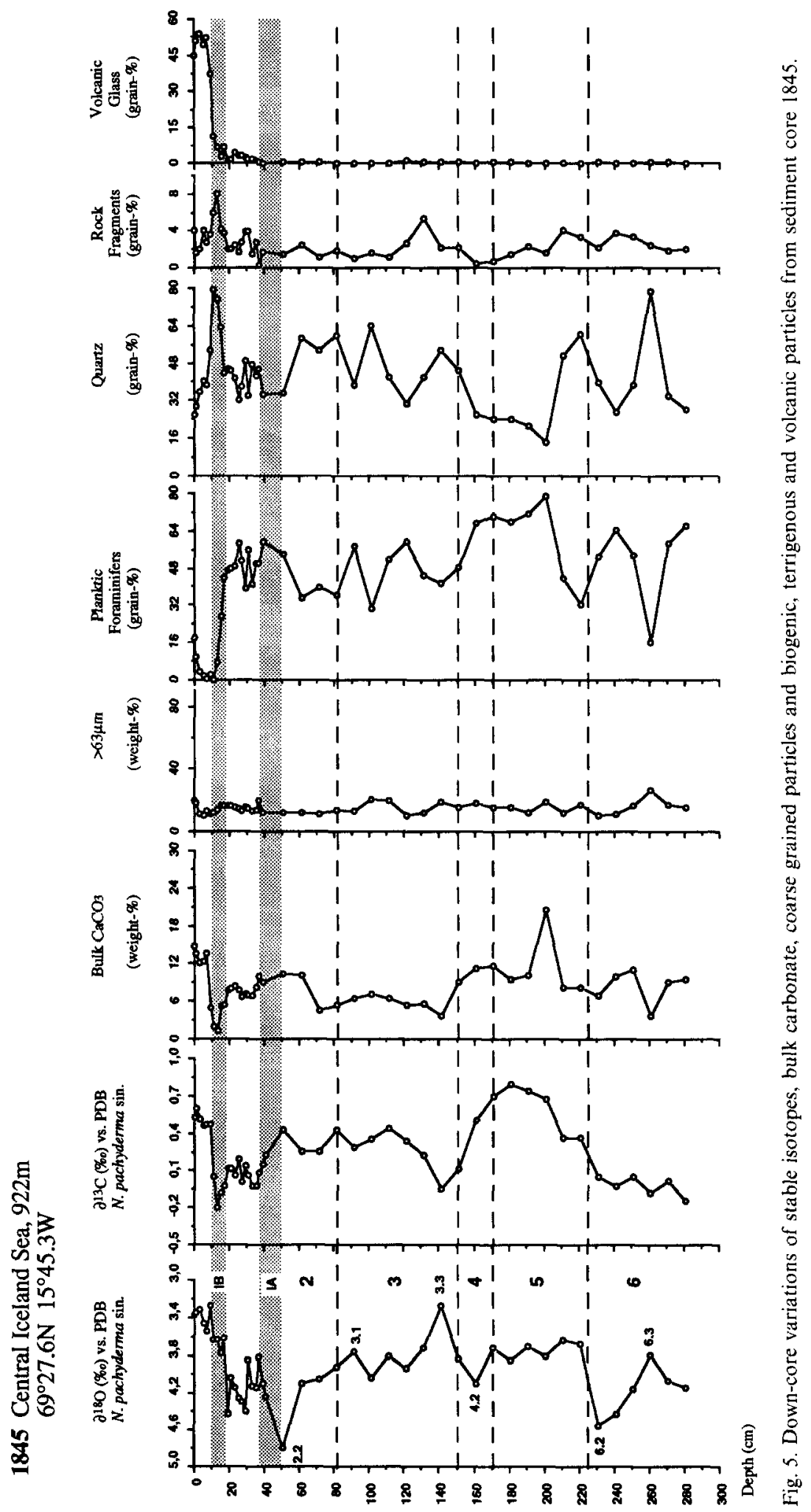


stage $6 / 5$ boundary. This is most obviously seen in cores 1845, 1852, 1900 and 1906 (Figs. 5-8). A significant terrigenous input is recorded in all cores at the isotope stage $2 / 1$ boundary. The sediment cores from the western Iceland Sea (core 1845) and Greenland Sea (cores 1900, 1748 and 1906) show a sharp increase in calcium carbonate content near the top of the cores above the isotope stage $2 / 1$ boundary. Although the increase in carbonate is less pronounced in cores 1852 and 1857, this event can also be identified.

\section{Calcium carbonate records of sediment cores}

Examination of the carbonate records generally reveals higher contents during interglacial stages, with the highest overall $\mathrm{CaCO}_{3}$ contents occurring in the northernmost core 1906 (Fig. 8). In glacial sediments carbonate is usually less than $10 \mathrm{wt} \%$, interrupted only by several distinct peaks during isotope stage 3 and stage 6 , respectively. These spikes are seen in most of the cores, such as core $1852(120 \mathrm{~cm})$, core $1900(230 \mathrm{~cm})$, and core 1906 $(100 \mathrm{~cm}$ and $265 \mathrm{~cm})$ (Figs. 6-8). The carbonate records show similar but less pronounced amplitude shifts in comparison to carbonate records underlying the Norwegian Atlantic Current.

Sediment cores from the Kolbeinsey Ridge (cores 1845, 1852 and 1857) are characterized by generally low carbonate values and low amplitude shifts. These cores do not show a high carbonate zone at the top except for the uppermost $10 \mathrm{~cm}$ of core 1845 (Fig. 5). In glacial sediments the calcium carbonate content usually decreases to values of $<10 \mathrm{wt} . \%$. It should be mentioned that relatively high carbonate values $(16-22 \mathrm{wt} . \%)$ in the cores 1852,1748 and $1906(100-120 \mathrm{~cm})$ during isotope stage 3 are due to calcareous nannofossils in addition to planktic foraminifers. The highest calcium carbonate contents are measured in oxygen isotope substage $5.5(15-20 \mathrm{wt} . \%)$ indicating an intensified inflow of North Atlantic surface waters into this area.

The cores west of Jan Mayen (cores 23345, 23343 and 1857) are characterized by the lowest calcium carbonate values $(<10 \mathrm{wt} . \%)$ and the lack of an obvious carbonate pattern in the glacial-interglacial record (Fig. 9). However, intervals nearly barren of carbonate in sediment cores 23343 (35-60 cm, 250-280 $\mathrm{cm}$ and $435-445 \mathrm{~cm}$ ) and 1875 (at about $280 \mathrm{~cm}, 400-430 \mathrm{~cm}$ ) can be interpreted as peak glacials. In general, the situation recorded here may represent quite uniform paleoceanographic conditions in this area during the last two glacial-interglacial cycles. A small, short-term increase in carbonate content $(12 \mathrm{wt} \%$ ) was observed in all three cores (core 23345, $210 \mathrm{~cm}$; core $23343,315 \mathrm{~cm}$; core $1875,290 \mathrm{~cm}$ ) during isotope stage 6 (Fig. 9).

The carbonate variations in cores from the central and northernmost Greenland Basin (cores 1900, 1748 and 1906) reflect spatially and temporally more variable surface water circulation patterns. Carbonate values and amplitudes are at a higher level than observed in the south of the study area. In contrast to these southernmost sediment cores, highest carbonate contents $(20-30 \mathrm{wt} . \%)$ are found in Holocene sediments, whereas the carbonate levels in oxygen isotope stage 5 are generally lower (15-20 wt.\%), only reaching the same low level as in the corresponding sediment intervals on the Kolbeinsey Ridge (Fig. 9). The carbonate contents in glacial sediments of these cores are characterized by higher amplitudes than observed in all the other cores. Distinct layers that are rich in calcium carbonate were found in the glacial sequences, best seen in core $1906(300 \mathrm{~cm}, 420 \mathrm{~cm})$ (Fig. 8). These layers consist almost exclusively of the polar planktic foraminifer $N$. pachyderma sin. (Bauch, 1992). Micro cross lamination and distinct horizontal stratification are typical sedimentological features of these layers. Hence, they are interpreted to be the result of contour currents. In contrast, sediments of glacial-interglacial transitions (e.g., core $1900,180-200 \mathrm{~cm}$; core $1906,235-260 \mathrm{~cm}, 400 \mathrm{~cm}$ ) and the basal parts of these cores are almost free of carbonate and barren in planktic foraminifers (Figs. 7 and 8).

\section{Terrigenous particle input in the sediment cores}

Detailed studies of the distribution of terrigenous components in the coarse fraction (125-500 $\mu \mathrm{m})$ show strong episodic fluctuations, which, in turn, reflect variations in ice-rafting. Generally, 


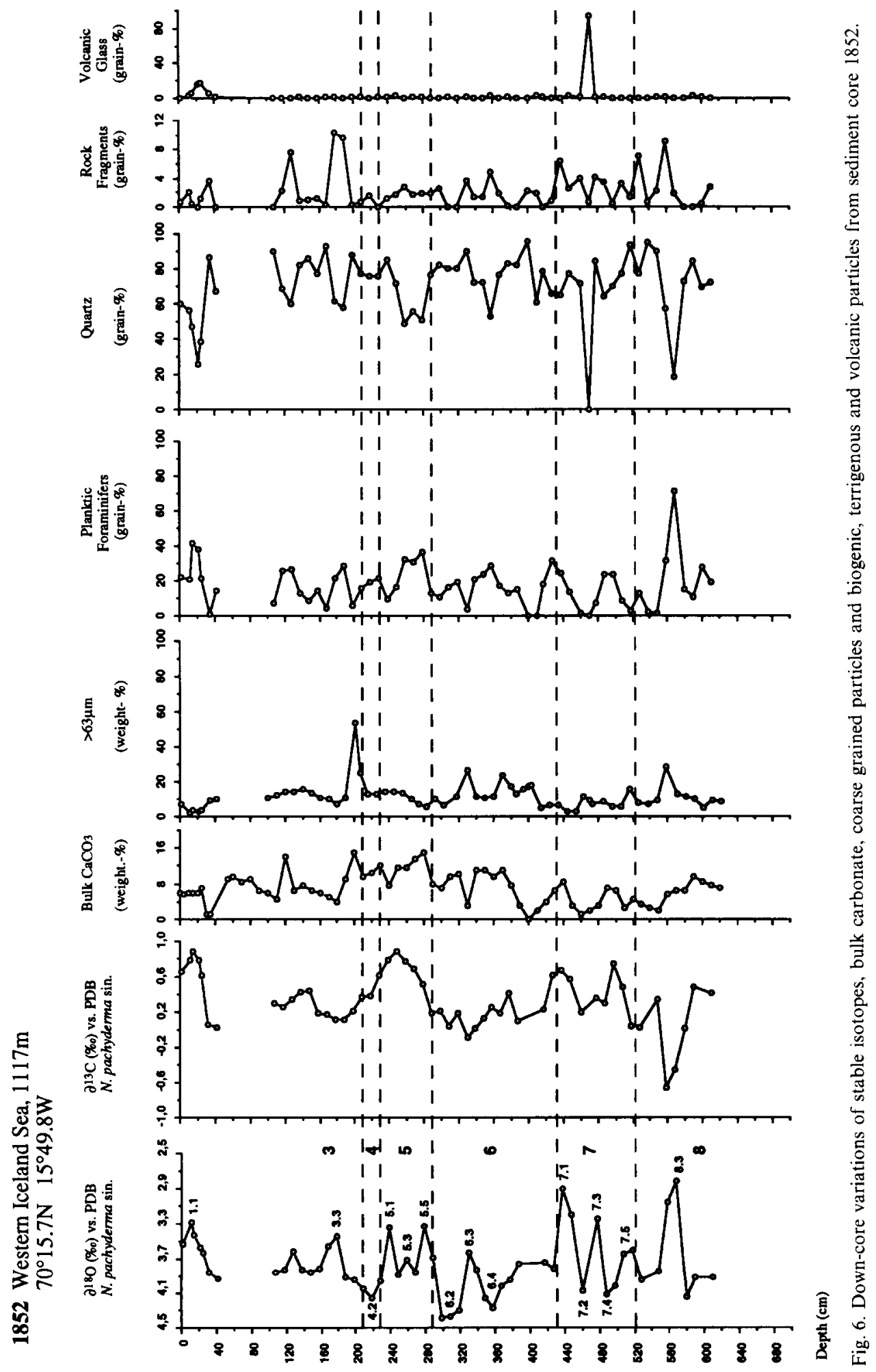




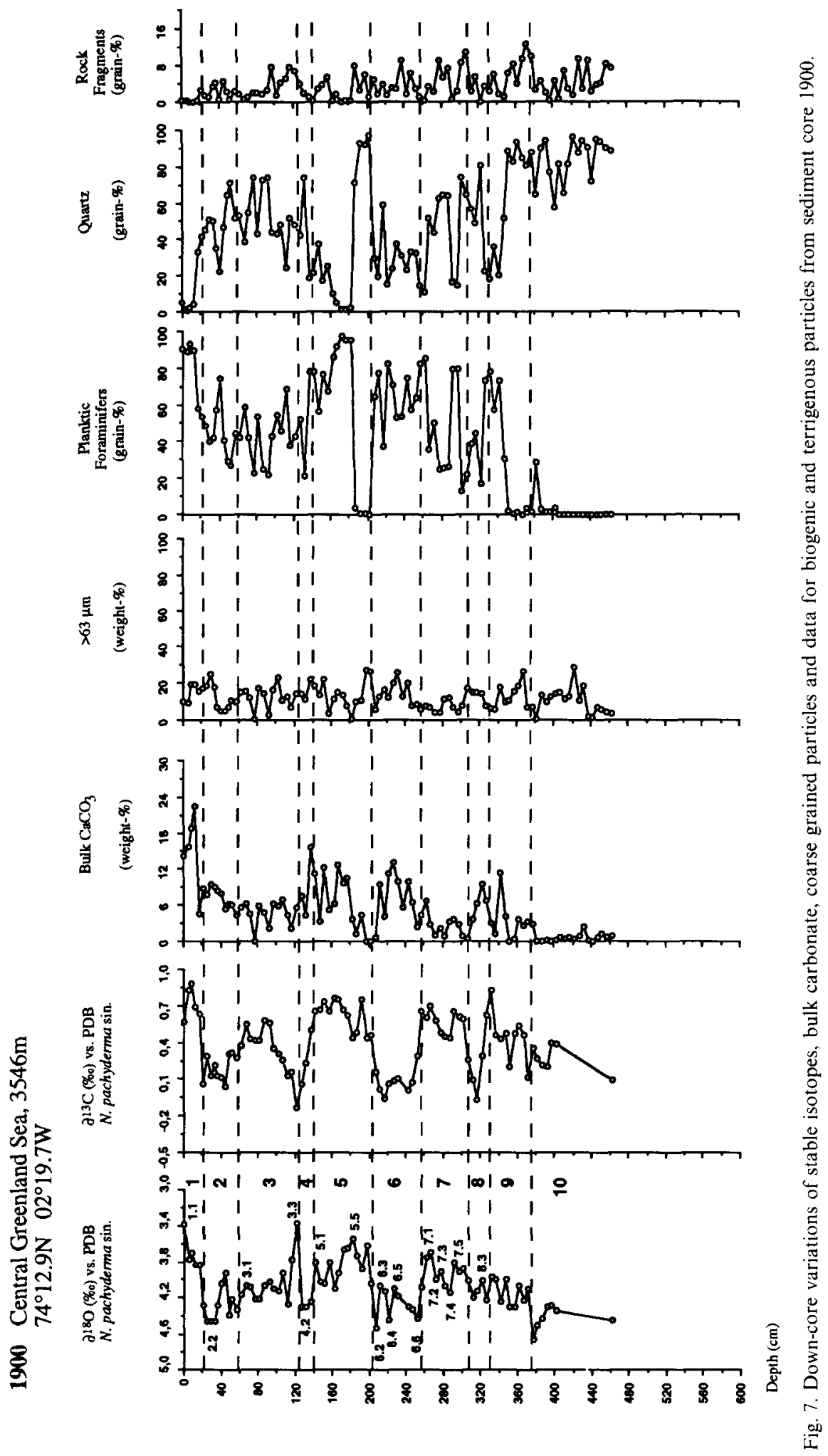




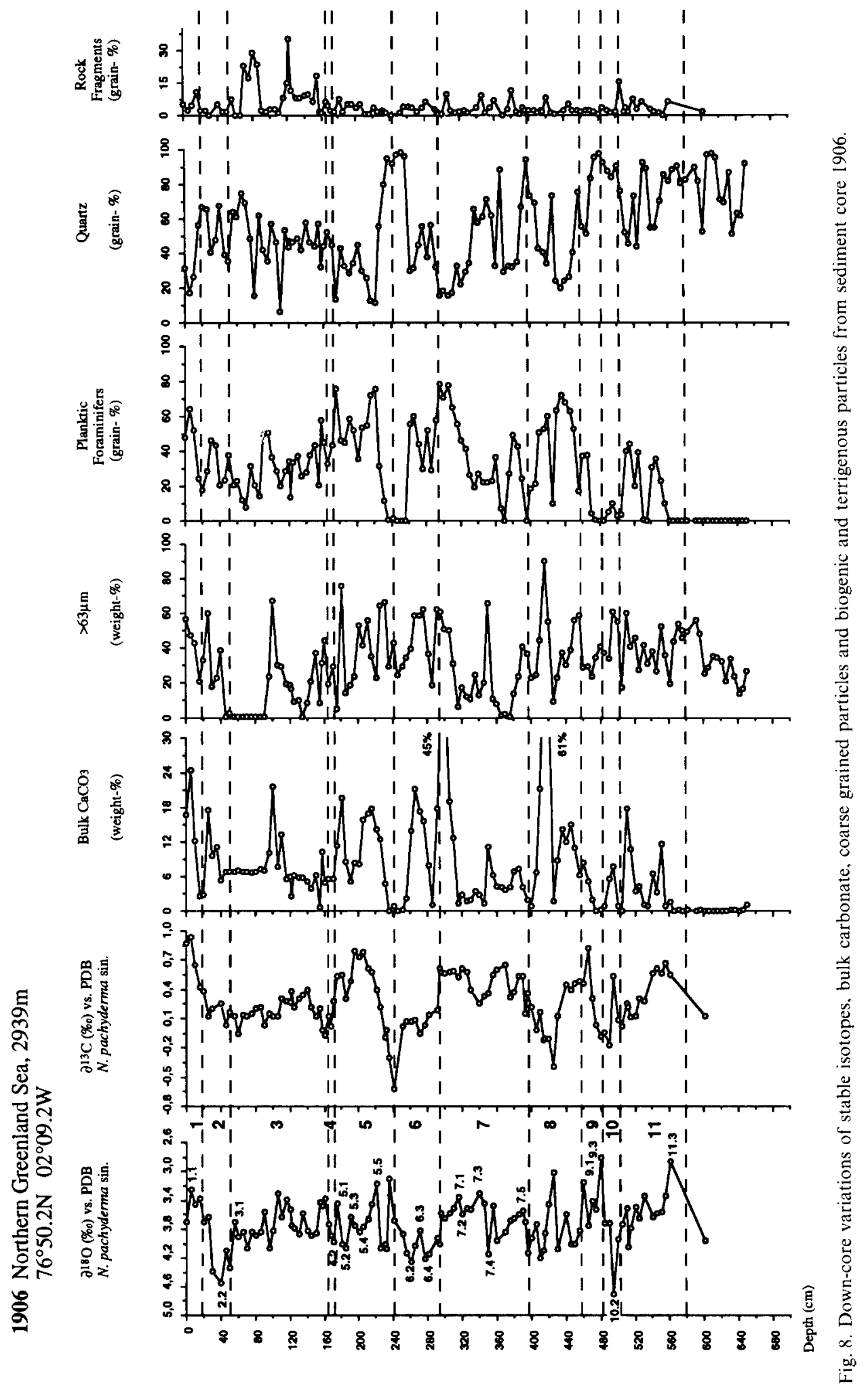


glacial age sediments contain layers with the highest amounts of terrigenous material (up to 100 grain-\%). The highest amounts of ice-rafted material (IRD) are also found at levels corresponding to the end of glacial stages 6 and 2 in all the cores studied. These layers are also characterized by a high portion of material $>63 \mu \mathrm{m}$ (Figs. 5-8).

However, core 1852 is rich in terrigenous particles (60-90 grain-\%) throughout the whole record. In cores 1900, 1748, and 1906, the basal parts of the cores are generally dominated by high terrigenous particle content ( $70-100$ grain- $\%)$. In addition, IRD peaks (up to $70-90$ grain \%) are found in core $1900(130 \mathrm{~cm}, 90 \mathrm{~cm}, 75 \mathrm{~cm}$ and $55 \mathrm{~cm})$, core $1906(155 \mathrm{~cm}, 120 \mathrm{~cm}, 85 \mathrm{~cm}, 70 \mathrm{~cm}$, $40 \mathrm{~cm}$ and $19 \mathrm{~cm})$, and core $1748(140 \mathrm{~cm}$ and $120 \mathrm{~cm}$ ) during the last glacial period (isotopic stages 4 to 2). Although these "Heinrich"-like layers (Heinrich, 1988) were not clearly found in the southern cores, some IRD-rich layers can also be seen in corresponding core sections. A drastic decrease of IRD is recorded at the isotope stage $6 / 5$ and $2 / 1$ transitions, most obviously seen in cores 1900, 1906 and 23343 (Figs. 6, 7 and 10). Low amounts of terrigenous particles were observed in early stage 5 sediments and in the uppermost $10-35 \mathrm{~cm}$ of all sediment cores studied (Fig. 10). However, in some glacial horizons values can also decrease to $<\mathbf{4 0}$ grain- $\%$.

Rock fragments and large dropstones consist of various igneous, metamorphic and sedimentary lithologies (Bischof, 1990; Lackschewitz, 1991). Dropstone assemblages generally consist of monocrystalline components (mostly quartz and feldspar), plutonic and metamorphic rocks such as granites, gneisses, quartzites, and clastic sediments (silt- and sandstones). Cretaceous chalk fragments are of special interest with respect to their limited occurrence in the northern North Atlantic area. Chalk is only exposed to glacial erosion on the southernmost Norwegian shelf (Rokoengen et al., 1989) and in the North Sea region (Hancock, 1984). Chalk fragments were observed only in core 1900 in sediments from late isotope stage 6 and stage 2, respectively (e.g., $300 \mathrm{~cm}, \quad 200 \mathrm{~cm}$; $17-41 \mathrm{~cm})$.

\section{Discussion and paleoceanographic implications}

\section{Recent sedimentation}

Bulk calcium carbonate contents of surface sediment samples provide a first approximation for differentiating the surface water masses in the Norwegian-Greenland Sea (Kellogg, 1975, 1976; Henrich et al., 1989). High contents of planktic foraminifers and coccolithophorids are found in plankton samples from the Atlantic water masses, especially from the Norwegian Current, indicating high calcium carbonate shell production (Samtleben and Schröder, 1992). In contrast, a low production of $\mathrm{CaCO}_{3}$ and relatively high calcium carbonate dissolution can be related to the Polar surface water masses (Samtleben and Schröder, 1992; Carstens and Wefer, 1992; Hebbeln and Wefer, 1992). Thus, the low calcium carbonate content in surface samples along the Greenland continental margin are due to low calcium carbonate production and low flux rates in the cold East Greenland Current. On the other hand, the relatively high carbonate content in the central Iceland Sea and northern Greenland Sea can be related to a higher production due to warmer Atlantic water masses. These observations are in good accordance with recent hydrographic data. Temperature profile measurements in the Greenland Sea show a tongue of warmer water in the upper $200 \mathrm{~m}$ along the Greenland Fracture Zone indicating westward-flowing Atlantic water (Quadfasel and Meincke, 1987).

It is tempting to infer that the measured $\mathrm{CaCO}_{3}$ records in the studied cores preliminary reflect variations in surface water carbonate shell production and may be modified in approximation to the Greenland continental margin by decreasing accumulation of $\mathrm{CaCO}_{3}$, as a consequence of dissolution, and by increasing dilution of terrigenous material. However, the regional distribution of carbonate accumulation rates in the surface sediments of the GIN Sea is clearly related to the surface water masses (Paetsch et al., 1992).

The transport mechanism for the terrigenous material in the high latitudes is interpreted to be ice-rafted. Other mechanisms include depositon of terrigenous debris by turbidity and contour cur- 
rents and wind-eroded sand transport (Fillon et al., 1981; Mienert et al., 1992). Winnowing of fine sediments by contour currents may also enhance the percentages of coarse terrigenous components at the continental margin. Similar observations were reported for the East Greenland continental margin off Fram Strait (Berner and Wefer, 1990) and off Kangerdlugssuaq Fjord (Mienert et al., 1992) where current winnowing of sediments is one of the dominant processes.

The sedimentation of the IRD is also controlled by surface water temperature. Sediment trap studies in the Fram Strait showed that the highest lithogenic particle flux occurred at the sea-ice edge in relatively warm water (Hebbeln and Wefer, 1991). In contrast, ice melting is inhibited in cold water $\left(<0^{\circ} \mathrm{C}\right)$, and although the ice contains high amounts of terrigenous material only small fluxes of IRD were observed. However, the terrigenous material is mostly supplied by floating icebergs or sea-ice which is, furthermore, largely responsible for a reduction in surface water calcium carbonate shell production. As a consequence, low production of calcium carbonate shells is associated with high terrigenous dilution, resulting in very low calcium carbonate values.

Distinctly higher amounts of coarse terrigenous particles are recorded on the Greenland continental shelf and margin as compared to the Greenland Basin and Iceland Plateau. This indicates that most of the ice-rafted terrigenous particles are deposited on the shelf and continental margin, whereas only minor amounts reach the basin. A similar sedimentological regime for the adjacent Fram Strait area was proposed by Berner and Wefer (1990). Paetsch et al. (1992) have shown that accumulation rates of terrigenous matter, calculated from the difference between bulk sediment and $\mathrm{CaCO}_{3}$ flux, increase towards the Greenland continent. Accordingly, the highest accumulation of terrigenous matter occurs in the northernmost Greenland Sea and is attributed to a high input of ice-rafted detritus, transported out of the Arctic Ocean.

The sediment surface data reveal that high carbonate contents together with low amounts of terrigenous particles indicate a relatively strong inflow of warm North Atlantic surface water masses. Little dilution by fine-grained terrigenous material points to a minor role of ice melting. In contrast, high amounts of coarse terrigenous material and low carbonate content reflect enhanced deposition of IRD, indicating that extensive melting of ice occurred in this area. Carbonate shell production is strongly reduced in the polar surface water masses. However, alternatives to explain the decreasing $\mathrm{CaCO}_{3}$ content can be dissolution of the pelagic shells or dilution by terrigenous particles.

\section{Paleoceanography during the last 450,000 years}

Major down-core variations of the calcium carbonate content and the relative abundance of terrigenous material strongly reflect variations in the general circulation pattern of surface water masses and in broader paleoclimatic conditions. Basically, the distribution pattern of carbonate in interglacials and late deglaciations reflects the dynamics of the extension of the Atlantic domain and its warmer surface waters. Previous studies of Greenland Sea sediments show that ice-rafting occurred during most of the past 450,000 years. It was also assumed that the Greenland Sea was permanently sea-ice-covered during most of this time (Kellogg, 1976).

The oldest sediments recorded in this study are from the Greenland Sea. They are assigned to levels as old as oxygen isotope stage 12 (core 1906) and comprise highest terrigenous contents (up to 100 grain-\%) up through the lower part of stage 9. Within these sections carbonate is generally low, and carbonate-free intervals occurred as well (Figs. 9 and 11). This indicates dominating polar conditions with a wide extent of continental ice masses and glaciers prevailing during these time intervals. The polar surface waters were interrupted only by very few short-termed inflows of warmer surface waters which are documented by calcium carbonate maxima. The slight increases in carbonate accumulation rates in parts of stage 11 and especially at the stage $10 / 9$ transition suggest a relatively high biological production rather than IRD input, while carbonate production was low in stages 10 (?) and 9 (Fig. 11). However, there is no evidence for strong influence of North Atlantic surface waters in the Greenland Sea during isotope stage 

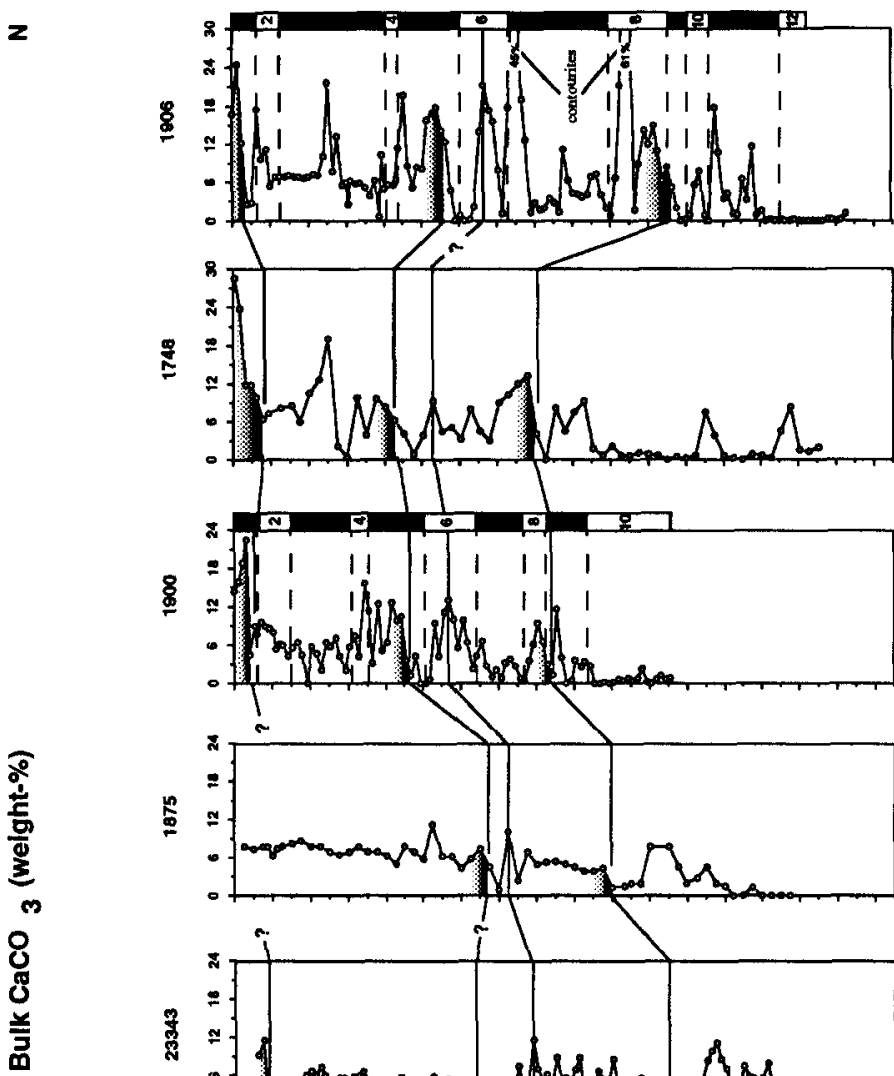

$z$

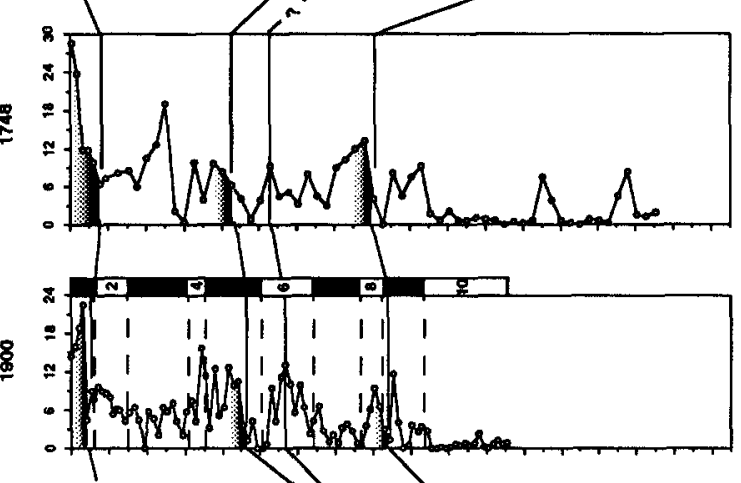

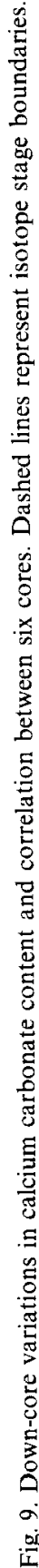




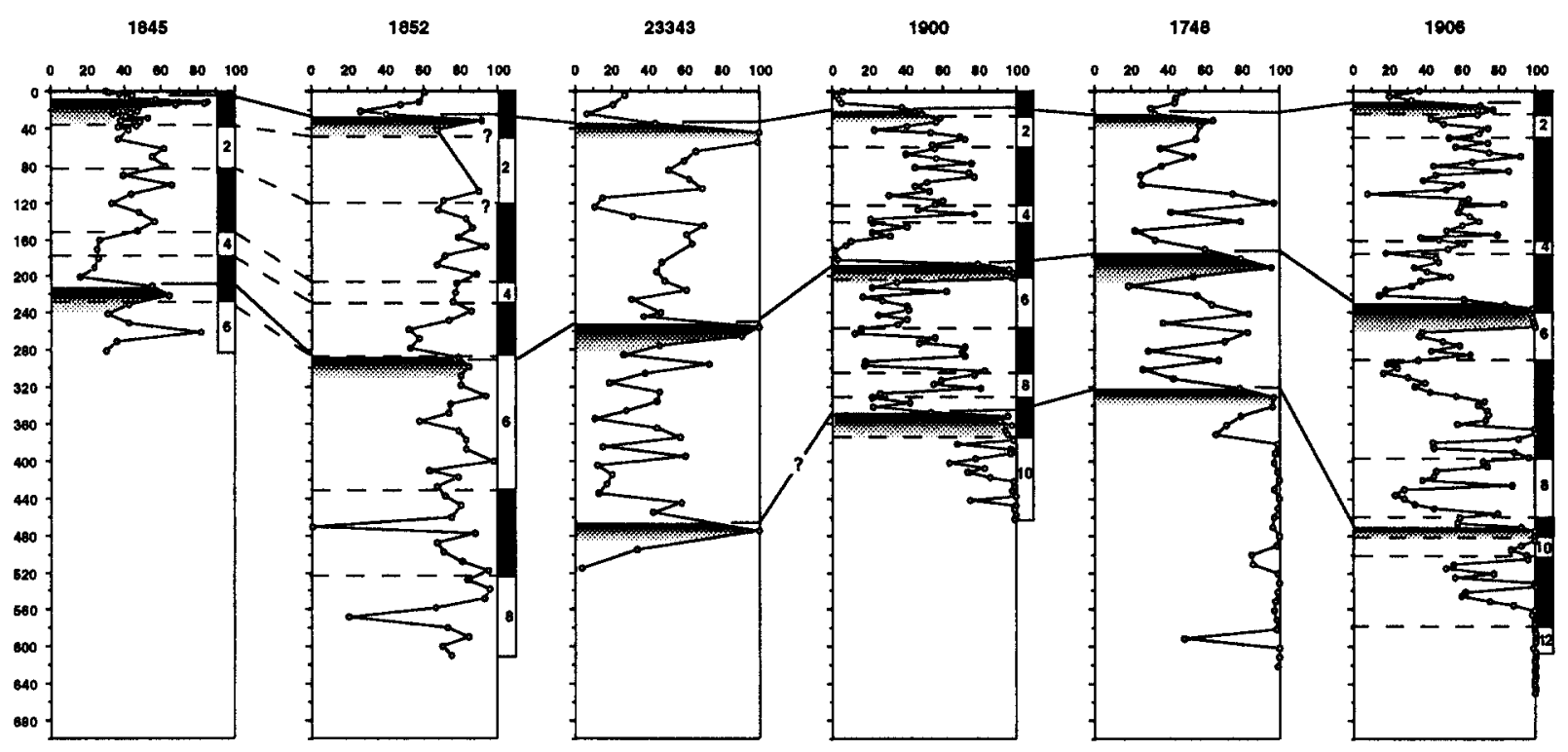

Depth (cm)

Fig. 10. Down-core variations in coarse terrigenous particle content and correlation between nine cores. Dashed lines represent isotope stage boundaries.

9 and especially during stage 11 , in contrast to a proposed strong influx into the Norwegian and Iceland Sea (Gard, 1988; Henrich, 1989; Baumann, 1990; Gard and Backman, 1990; Bauch, 1992). This seems to indicate a strengthening of the oceanographic fronts and warm surface currents not penetrating as far westward as today.

A first major decrease in terrigenous particle supply together with an increase in carbonate content close to the stage $9 / 8$ boundary (Figs. 9 and 10), indicates a change from a dominating polar surface water regime to a warmer climate with seasonal variation of the sea-ice cover. This should have resulted in an increase of carbonate shell production during the following interglacials. However, $\mathrm{CaCO}_{3}$ contents were highest in glacial stages 8 and 6 , whereas interglacial stage 9 and early stage 7 reveal low carbonate values only and high IRD contents (Figs. 9 and 10). In general, this is supported by the carbonate accumulation rates (Fig. 11), which show the same pattern. Therefore, it can be suggested that relatively warm North Atlantic surface water reached its northwesternmost expansions at about the location of the studied cores. Conditions were marked by significant amounts of floating sea-ice and icebergs melting and depositing their load of IRD in this area. This is also supported by the first occurrence of chalk fragments in the central Greenland Sea (core 1900) at the beginning of stage 7. These chalk dropstones were most likely transported by northward-floating icebergs, since the northernmost deposits of chalk are only known from the North Sea area south of $59^{\circ} \mathrm{N}$ (Hancock, 1984). North of $59^{\circ} \mathrm{N}$, upper Cretaceous sediments are mostly clastic and chalk is absent. Thus, icebergs must have been carried northward by surface currents and melted in the central Greenland Sea. A relatively weak interglacial circulation during isotope stages 9 and 7 is also supported by generally low to intermediate carbonate values in the eastern GIN Sea (Henrich et al., 1989). During glacials IRD deposition was much lower, most probably due to a more stable Greenland Ice Sheet and only little ice melting in this area.

The pronounced peaks of volcanic ash in the southernmost cores $(1852,1857)$ in sediments from oxygen isotope stage 7 (see Figs. 5 and 6) also 
S

\section{Accumulation Rates of $\mathrm{CaCO}_{3}\left(\mathrm{gcm}^{-2} \mathrm{ka}^{-1}\right)$}

$\mathbf{N}$

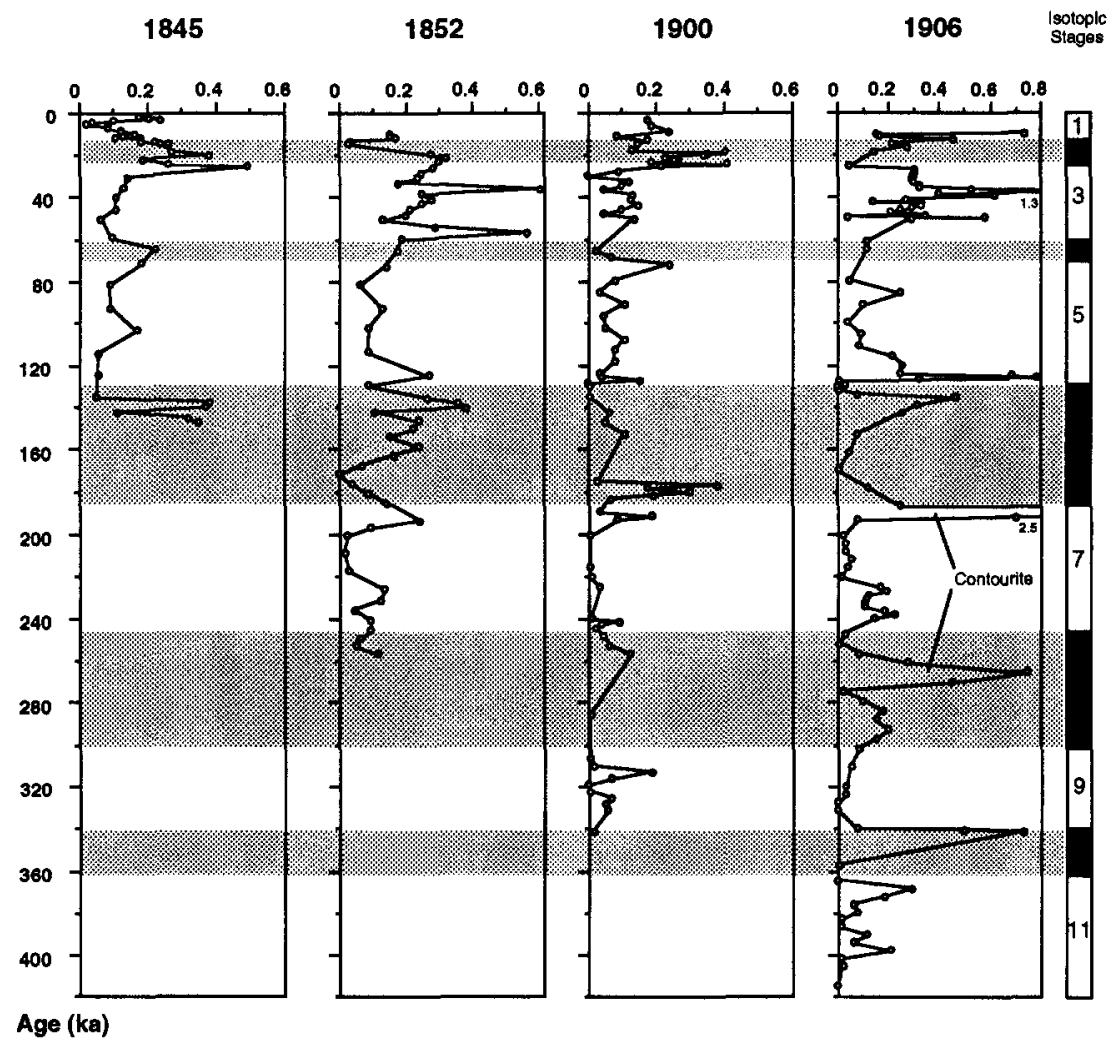

Fig. 11. Down-core variations of accumulation rates of $\mathrm{CaCO}_{3}\left(\mathrm{~g} \mathrm{~cm}^{-2} \mathrm{kyr}^{-1}\right)$ from cores 1845, 1852, 1900 and 1906. Peak carbonate accumulation rates within glacial sediments (especially during stages 6,3 and 2) seems to be an artefact of the calculation method (using linear sedimentation rates).

indicate periods with at least seasonally open water, thus permitting the ash particles to reach the sea-floor. This has already been proposed for the Norwegian Sea and Iceland Sea ash layers from interglacial stages (Sigurdsson and Loebner, 1981; Sejrup et al., 1989, Lackschewitz, 1991). The coincidence of the ashes with interglacial periods is related to increased volcanic activity following the major deglaciation events of the Iceland ice cap (Sejrup et al., 1989).

Generally, the supply of coarse terrigenous particles was high at core site 1852 throughout the record, probably because of the location close to the Greenland continental margin. Together with low but constant calcium carbonate values, this documents a relatively stable environment on the westernmost Iceland Plateau, which was only scarcely influenced by warmer surface waters during the last $250 \mathrm{kyr}$.

At the end of glacial stage 6 a significant terrigenous input is seen in all cores and record a period of major melting events. Henrich et al. (1989) have already shown for the Norwegian Sea that sediment fluxes were highest during these late glacial/ early deglacial periods. Simultaneously planktic isotope curves exhibit extremely light $\delta^{18} \mathrm{O}$ values along with depleted $\delta^{13} \mathrm{C}$ values, most obviously seen in cores 1900 and 1906 (Figs. 7 and 8) and were interpreted as the isotopic response to the meltwater discharge at the end of stage 6 . Correspondingly, light oxygen isotope values also point to a meltwater event in the Greenland Sea. In addition, very low $\delta^{18} \mathrm{O}$-values and $\delta^{13} \mathrm{C}$ depleted carbon isotope ratios along with high 
amounts of IRD during isotopic events 9.1, 8.3, 7.1 and 3.3 are interpreted to reflect phases of large regionally important meltwater discharges into the GIN Sea. The early meltwater events after the Last Glacial Maximum have been extensively studied (Jones and Keigwin, 1988; Jones, 1991; Weinelt et al., 1991; Sarnthein et al., 1992). A rapid decrease of ice-rafted material after the early deglacial period of isotope stage 5 (isotopic event 5.5.3) along with a change to particle assemblages dominated by pelagic carbonates points to a further intensified inflow of warm North Atlantic surface waters into the western GIN Sea. This situation culminated at isotopic event 5.5.1, as is clearly documented by high calcium carbonate values, light oxygen isotopes, and a minimum of terrigenous particles. However, $\mathrm{CaCO}_{3}$ values are not as high as compared to the Holocene, most probably because the warm surface currents did not penetrate as far westwards as today.

The records between isotope substages 5.5 and 5.1 are marked by low carbonate values, suggesting that warm Atlantic water only scarcely reached the western GIN Sea. Highest carbonate contents in the Greenland Sea are found during isotope substage 5.1. However, carbonate accumulation rates are higher in substage 5.5.1 in core 1906 (Fig. 11). This indicates that during isotope event 5.1 the rather small, still persisting ice sheets were more or less stable, so that contrary to the stage $6 / 5$ transition calcium carbonate reached a maximum due to the decreasing supply of diluting matter. Simultaneously, a decreasing stability of the water column stratification allowed a deepreaching convection and led to an increased fertility of the surface waters (Haake et al., 1991). Highest abundances of coccoliths in Fram Strait were also found in substage 5.1 sediments and not in substage 5.5 (Gard and Backman, 1990). Marine fauna and terrestrial flora and fauna in East Greenland shows that both sea surface temperature and atmospheric climate were warmer in isotopic substage 5.1 than during the Holocene (Funder et al., 1991).

Oxygen isotope stage 4 is characterized by an increase of terrigenous material, i.e. a return to strong polar conditions. Although the glacial sediments are characterized by high amounts of IRD, some peaks with ice-rafted detritus are recorded for the last glacial period at $\delta^{18} \mathrm{O}$-estimated ages of $49,42,30,22$ and $10-15 \mathrm{ka}$ (Fig. 12). The synchronism of these peaks to most of the horizons rich in ice-rafted debris and unusually poor in planktic foraminifers in northern North Atlantic sediments as first recognized by Heinrich (1988) is remarkable. Subsequent studies (Broecker et al., 1992; Bond et al., 1992; Grousset et al., 1993) reveal that these deposits extend across the entire Atlantic. The so-called "Heinrich"-layers (H1-H6) seem to record massive discharges of icebergs and are suggested to be the product of sudden advances of ice streams onto the shelves. Broecker et al. (1992) and Bond et al. (1992) assumed that the northern ice sheets could be affected by large pseudoperiodic surges. Some of the "Heinrich"layers (like $\mathrm{H} 3$ ) must have originated in eastern Greenland or in the Scandinavian Ice Sheets as indicated by their $\mathrm{Nd}-\mathrm{Sr}$ isotopic composition (Grousset et al., 1993). Thus, the observed IRD peaks most probably reflect surges of the Greenland and Scandinavian ice sheets. Previous studies have indicated that correlative advances of the Scandinavian and Barents Sea ice sheets can be seen in the eastern GIN Sea (Baumann et al., 1993). This suggested that large portions of the Northern Hemisphere ice sheets advanced synchronously and reflects globally important climatic changes on timescales inconsistent with Milankovitch orbital periodicities.

In the same time interval, the carbonate content probably indicates a reduced inflow of warm Atlantic surface waters in the western GIN Sea especially during stage 3 . The strong increase in carbonate accumulation rates during this time interval (Fig. 11) is suggested to be an artefact of the calculation method, which is also described and discussed for the eastern NorwegianGreenland Sea (Henrich et al., 1989). The linear sedimentation rates which were calculated between age fix points could result into high values for the carbonate-bearing deposits within this interval. Low abundances of coccoliths nevertheless suggest that some warmer surface waters must have influenced the Greenland Sea as far north as the Fram Strait (Gard, 1988; Gard and Backman, 1990). 


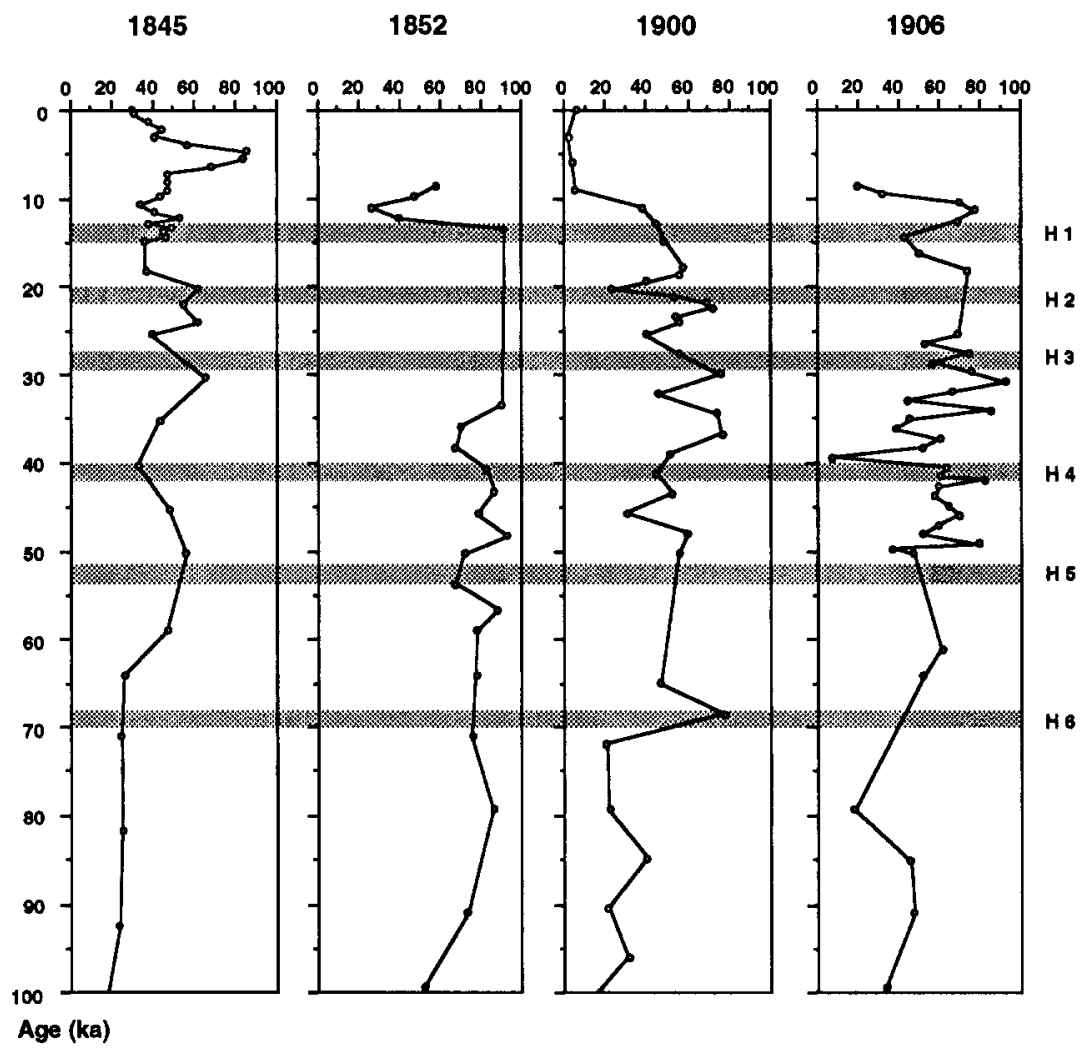

Fig. 12. Down-core variations of terrigenous particles (grain-\%) versus age focused on the uppermost 100 ka. Dotted bands indicate time intervals of "Heinrich" events (H1-H6) in northern North Atlantic (ages after Bond et al., 1992).

However, Henrich et al. (1989) have proposed an influx of Atlantic waters into the eastern Norwegian Sea during parts of isotope stage 3. Reduced dilution by terrigenous material during this period may also have contributed to the increase of calcium carbonate.

Generally low calcium carbonate content in stage 2 may indicate a quite stable depositional regime dominated by polar conditions with at least a seasonal sea-ice cover. In the Greenland basin ice-rafted material is characterized by chalk fragments (core 1900). Therefore, the high carbonate accumulation rates in core 1900 during this glacial period may reflect enhanced influx of resedimented, ice-eroded chalk dropstones and fine-fraction carbonate (e.g. Cretaceous chalks). A prominent increase in carbonate content and in the amount of planktic foraminifers can be seen in most of the cores during the early phase of oxygen isotope stage 1 (Figs. 5-9). This increase in planktic carbonate production is parallel to Termination $I_{B}$ and is in good agreement with other results from the adjacent Norwegian Sea (Kellogg et al., 1978; Sejrup et al., 1984; Jansen and Bjørklund, 1985; Henrich et al., 1989; Baumann and Matthiessen, 1992). However, a distinct contrast between the Greenland Sea and the Iceland Sea can be observed. The higher carbonate values in the northern cores indicate a rather strong influence of North Atlantic surface waters. In contrast, the areas east of Kolbeinsey Ridge and east of Jan Mayen are dominated by eastward intrusions of cold East Greenland Current waters during the Holocene. 


\section{Conclusions}

The calcium carbonate content of surface sediments in the western part of the GreenlandIceland-Norwegian (GIN) Sea reflects the basical pattern of the modern surface water circulation, especially the westward penetration of Atlantic surface water masses in the northern Greenland Sea and in the northeastern Iceland Sea.

The down-core variations in oxygen isotope composition, calcium carbonate content and coarse terrigenous input indicate major paleoceanographic changes. Distinct shifts in these parameters can also be used for stratigraphic purposes of the past $350 \mathrm{kyr}$. However, local conditions have irregularly modified and dominated the overall trends. The different records permit the following conclusions:

- Coarse sediment deposition is primarily related to glacial intervals. Maxima in the input of icerafted lithic fragments were observed especially at the end of glaciations close to the terminations, indicating massive melting of icebergs in the western GIN Sea. The peak input of debris is often associated with light $\delta^{18} 0$ values.

- The high input of ice-rafted detritus was followed by an increase in calcium carbonate production caused by maximum intrusion of warm Atlantic surface waters. Changes in calcium carbonate contents indicate a variable contribution of relatively warm Atlantic surface water to the Greenland and Iceland Seas, although the amplitudes are much less pronounced than in records beneath the Norwegian Current.

- Extensive IRD deposition in the older core intervals occurred until about isotope stage 9 . This documents a relatively stable environment in this area, strongly influenced by relatively cold surface water masses.

- Cores west of Jan Mayen are characterized by the lack of an obvious calcium carbonate pattern in the glacial-interglacial record. The situation recorded here may represent rather uniform paleoceanographic conditions only interrupted by a very short incursion of slightly warmer water during oxygen isotope stage 5 .

- During stage 5, conditions were more uniform indicating a less pronounced westward penetration of Atlantic waters as compared to the Holocene. However, conditions west of Jan Mayen seem to have remained constant throughout the whole time investigated.

-The last glacial (stages 4-2) is characterized by the occurrence of "Heinrich"-like events, although high IRD contents were present throughout this interval. The synchronism of these peaks to most of the "Heinrich-layers" in northern North Atlantic sediments is remarkable.

- During the Holocene the northernmost cores are characterized by high amounts of carbonate. In contrast, the cores in the south show generally low calcium carbonate values. This pattern is indicative of a rather strong westward penetration of Atlantic water in the north and of a cold water dominated area east of the Kolbeinsey Ridge associated with an eastward intrusion of cold water near Jan Mayen.

\section{Acknowledgements}

We gratefully acknowledge H. Chamley, W.F. Ruddiman and R.F. Spielhagen for their critical discussions and valuable comments. $\mathrm{H}$. Cordt, I. Klein and $\mathrm{H}$. Hecht took care of and operated the mass spectrometer. H. Kassens provided an unpublished set of physical property data, which is gratefully acknowledged. C. Hoffmann improved the English. A. Hamich provided additional samples. For technical assistance, we thank A. Schröder, A. Kohly and D. Rau. We acknowledge the assistance of R.V. Polarstern's crew and captain during ARK VII/1 Cruise. This study was supported by grants from the Bundesministerium für Forschung und Technologie (Grant MFG 00664) and from the Deutsche Forschungsgemeinschaft (Sonderforschungsbereich 313, Contribution No. 191).

\section{References}

Bauch, H., 1992. Planktische Foraminiferen im Europäischen Nordmeer-ihre Bedeutung für die paläo-ozeanographische Interpretation während der letzten 600,000 Jahre. Ph.D. Thesis, Sonderforschungsbereich 313, Univ. Kiel, 95 pp.

Baumann, K.-H., 1990 . Veränderlichkeit der Coccolithophoridenflora des Europäischen Nordmeeres im Jungquartär. Ber. Sonderforschungsbereich 313, Univ. Kiel, 22: $1-146$. 
Baumann, K.-H. and Matthiessen, J., 1992. Variations in surface water mass conditions in the Norwegian Sea: evidence from Holocene coccolith and dinoflagellate cyst assemblages. Mar. Micropaleontol., 20: 129-146.

Baumann, K.-H., Henrich, R., Lackschewitz, K.S., Spielhagen, R.F., Wolf, T.C.W. and Mangerud, J., 1993. Glacial history of the Scandinavian Ice sheet: A marine-terrestrial correlation. Terra Abstr. (Abstract Suppl. No. 1 to Terra Nova), 5: 737.

Berner, H. and Wefer, G., 1990. Physiographic and Biologic factors controlling surface sediment distribution in the Fram Strait. In: U. Bleil and J. Thiede (Editors), Geologic History of the Polar Oceans: Arctic versus Antarctic. (NATO ASI Ser. C, 308.) Kluwer, Dordrecht, pp. 317-335.

Bischof, J., 1990. Dropstones in the Norwegian-Greenland Sea-Indications of a late Quaternary circulation pattern? In: U. Bleil and J. Thiede (Editors), Geologic History of the Polar Oceans: Arctic versus Antartic. (NATO ASI Ser. C, 308.) Kluwer, Dordrecht, pp. 499-518.

Bond, G., Heinrich, H., Broecker, W., Labeyrie, L., McManus, J., Andrews, J., Huon, S., Jantschik, R., Clasen, S., Simet, C., Tedesco, K., Klas, M., Bonani, G. and Ivy, S., 1992. Evidence for massive discharges of ivebergs into the North Atlantic ocean during the last glacial period. Nature, 360: 245-249.

Broecker, W., Bond, G., Klas, M., Clark, E. and McManus, J., 1992. Origin of the northern Atlantic's Heinrich events. Climate Dynamics, 6: 265-273.

Carstens, J. and Wefer, G., 1992. Recent distribution of planktonic foraminifera in the Nansen Basin, Arctic Ocean. DeepSea Res., 39(S2A): S507-S524.

Ehrmann, W. and Thiede, J., 1985. History of Mesozoic and Cenozoic sediment fluxes to the North Atlantic Ocean. Contrib. Sedimentol., 15, 109 pp.

Fillon, R.H., Miller, G.H. and Andrews, J.T., 1981. Terrigenous sand in Labrador Sea hemipelagic sediments and paleoglacial events on Baffin Island over the last 100,000 years. Boreas, 10: 107-124.

Funder, S., Hjort, C. and Kelly, M., 1991. Isotope stage 5 (130-74 ka) in Greenland, a review. Quat. Int., 10-12: 107-122.

Gard, G., 1988. Late Quaternary calcareous nannofossil biochronology and paleo-oceanography of Arctic and Subarctic Seas. Medd. Stockholms Univ. Geol. Inst., 275: 1-45.

Gard, G. and Backman, J., 1990. Synthesis of Arctic and SubArctic coccolith biochronology and history of North Atlantic Drift Water influx during the last 500,000 years. In: U. Bleil and J. Thiede (Editors), Geologic History of the Polar Oceans: Arctic versus Antartic. (NATO ASI Ser. C, 308.) Kluwer, Dordrecht, pp. 417-435.

Grousset, F.E., Labeyrie, L., Sinko, J.A., Cremer, M., Bond, G., Duprat, J., Cortijo, E. and Huon, S. 1993. Patterns of ice-rafted detritus in the glacial North Atlantic $\left(40-55^{\circ} \mathrm{N}\right)$. Paleoceanography, 8(2): 175-192.

Haake, F.-W., Erlenkeuser, H. and Pflaumann; U., 1992. Pullenia bulloides (Orbigny) in sediments of the Norwegian/Greenland Sea and the northeastern Atlantic Ocean: Paleo-oceanographic evidence. In: Studies in Benthic Foraminifera. Proc. Benthos '90. (Sendai, Japan, 1990.) Tokai Univ. Press, pp. 235-244.
Hancock, J.M., 1984. Cretaceous. In: K.W. Glennie (Editor), Introduction to the Petroleum Geology of the North Sea. Blackwell, Oxford, pp. 133-150.

Hebbeln, D. and Wefer, G., 1991. Effects of ice coverage and ice-rafted material on sedimentation in the Fram Strait. Nature, 350: 409-411.

Heinrich, H., 1988. Origin and consequences of cyclic ice rafting in the northeast Atlantic Ocean during the past 130,000 years. Quat. Res., 29: 143-152.

Henrich, R., 1986. A calcite dissolution pulse in the Norwegian-Greenland Sea during the last deglaciation. Geol. Rundsch., 75(3): 805-827.

Henrich, R., 1989. Glacial/interglacial cycles in the Norwegian Sea: Sedimentology, paleoceanography, and evolution of late Pliocene to Quaternary Northern Hemisphere climate. Proc. ODP, Sci. Results, 104: 183-2002.

Henrich, R., 1990. Cycles, rhythms, and events in Quaternary Arctic and Antarctic glaciomarine deposits. In: U. Bleil and J. Thiede (Editors), Geologic History of the Polar Oceans: Arctic versus Antarctic. (NATO ASI Ser. C, 308.) Kluwer, Dordrecht, pp. 213-244.

Henrich, R., Kassens, H., Vogelsang, E. and Thiede, J., 1989. Sedimentary facies of glacial-interglacial cycles in the Norwegian Sea during the last $350 \mathrm{ka}$. Mar. Geol., 86: 283-319.

Holler, P. and Kassens, H., 1989. Sedimentphysikalische Eigenschaften aus dem Europäischen Nordmeer (Datenreport F.S. Meteor, Reise 7). Ber. Sonderforschungsbereich 313, Univ. Kiel, 15: 1-61.

Holtedahl, H., 1959. Geology and paleontology of Norwegian Sea bottom cores. J. Sediment. Petrol., 29: 16-29.

Hirschleber, H., Theilen, F., Balzer, W., Von Bodungen, B. and Thiede, J., 1988. Forschungsschiff Meteor, Reise 7, Cruise Report. Ber. Sonderforschungsbereich 313, Univ. Kiel, 10, 358 pp.

Imbrie, J., Hays, J.D., Martinsson, D.J., McIntyre, A., Mix, A.C., Morley, J.J., Pisias, N.G., Prell, W.L. and Shackleton, N.J., 1984. The orbital theory of Pleistocene climate: Support from a revised chronology of the marine $\delta^{18} \mathrm{O}$ record. In: A.L. Berger, J. Imbrie, J. Hays, G. Kukla and B. Saltzman (Editors), Milankovitch and Climate. (NATO ASI Ser. C, 126.) Kluwer, Dordrecht, 1: 269-305.

Jansen, E. and Bjørklund, K.R., 1985. Surface ocean circulation in the Norwegian Sea 15,000 B.P. to present. Boreas, 14: 243-257.

Jansen, E., Sejrup, H.P., Ejaeran, T., Hald, M., Holtedahl, H. and Skarbo, O., 1983. Late Weichselian paleoceanography of the Southeastern Norwegian Sea. Nor. Geol. Tidsskr., 63: $117-146$.

Johannessen, O., 1986. Brief overview of the physical oceanography. In: B.G. Hurdle (Editor), The Nordic Seas. Springer, New York, pp. 103-127.

Jones, G.A., 1991. Spatial and temporal distribution of Laurentide and Fennoscandian meltwater during the last deglaciation. Nor. Geol. Tidsskr., 71: 145-148.

Jones, G.A. and Keigwin, L.D., 1988. Evidence from Fram Strait $\left(78^{\circ} \mathrm{N}\right)$ for early deglaciation. Nature, 336: 56-59.

Kassens, H,, 1990. Verfestigte Sedimentlagen und seismische Reflektoren: Frühdiagenese und Paläo-Ozeanographie in der 
Norwegischen See. Ber. Sonderforschungsbereich 313, Univ. Kiel, 24: 1-117.

Kellogg, T.B., 1975. Late Quaternary climatic changes in the Norwegian-Greenland Sea. In: S.A. Bowling and G. Weller (Editors), Climate of the Arctic. Univ. Alaska, Fairbanks, pp. 3-36.

Kellogg, T.B., 1976. Paleoclimatology and paleoceanography of the Norwegian and Greenland Seas: The last 450,000 years. Mar. Micropaleontol., 2: 235-249.

Kellogg, T.B., 1980. Paleoclimatology and Paleoceanography of the Norwegian-Greenland Sea: Glacial-interglacial contrasts. Boreas, 9: 115-137.

Koç Karpuz, N. and Jansen, E., 1992. A high-resolution diatom record of the last deglaciation from the SE Norwegian Sea: Documentation of rapid climatic changes. Paleoceanography, 7(4): 499-520.

Krause, G., Meincke, J. and Schwarz, H.J., 1991. Scientific Cruise Reports of Arctic Expeditions ARK VI/1-4 of R.V. "Polarstern" in 1989. Rep. Pol. Res., 87, 110 pp.

Lackschewitz, K.S., 1991. Sedimentationsprozesse am aktiven mittelozeanischen Kolbeinsey Rücken, nördlich von Island. Geomar Rep., 9: 1-133.

Martinsson, D.G., Nicklas, G.P., Hays, J.D., Imbrie, J., Moore, T.C. and Shackleton, N.J., 1987. Age dating and the orbital theory of the ice ages: development of a high-resolution 0 to 300,000 years chronostratigraphy. Quat. Res., 27(1): 1-29.

Mienert, J., Andrews, J.T. and Milliman, J.D., 1992. The East Greenland continental margin $\left(65^{\circ} \mathrm{N}\right)$ since the last deglaciation: Changes in seafloor properties and ocean circulation. Mar. Geol., 106: 217-238.

Müller, G. and Gastner, M., 1971. The "Karbonat Bombe", a simple device for the determination of the carbonate content in sediments, soils and other materials. Neues Jahrb. Miner. Monatsh., 1971: 466-469.

Paetsch, H., Botz, R., Scholten, J.C. and Stoffers, P., 1992. Accumulation rates of surface sediments in the Norwegian-Greenland Sea. Mar. Geol., 104: 19-30.

Quadfasel, D. and Meincke, J., 1987. Note on the thermal structure of the Greenland Sea gyres. Deep-Sea Res., 34: 1883-1888.

Ramm, M., 1989. Late Quaternary carbonate sedimentation and paleoceanography in the eastern Norwegian Sea. Boreas, 18: $255-272$.
Rokoengen, K., Gunsleikrud, T., Lien, R.L., Løfaldi, M., Rise, L., Sindre, E. and Vigram, J.O., 1980. Shallow geology on the continental shelf off Møre and Romsdal, Description of the $1: 25.000$ Quaternary geological map 6203, IKU Publ., 105: 1-49.

Samtleben, C. and Schröder, A., 1992. Living coccolithophore communities in the Norwegian-Greenland Sea and their record in sediments. Mar. Micropaleontol., 19: 333-354.

Sarnthein, M., Jansen, E., Arnold, M., Duplessy, Erlenkeuser, H., Flatoy, A., Veum, T., Vogelsang, E. and Weinelt, M.S., 1992. $\delta^{18} \mathrm{O}$ time-slice reconstruction of meltwater anomalies at termination $I$ in the North Atlantic between 50 and $80^{\circ} \mathrm{N}$. In: E. Bard and W.S. Broecker (Editors), The Last Deglaciation: Absolute and Radiocarbon Chronologies. (NATO ASI Ser. I, Global Environmental Change, 2.) Springer, Berlin, pp. 183-200.

Sejrup, H.P., Sjoholm, J., Furnes, H., Beyer, I., Eide, L., Jansen, E. and Mangerud, J., 1989. Quaternary tephrachronology on the Iceland Plateau, north of Iceland. J. Quat. Sci., 4: 109-114.

Sigurdsson, H. and Loebner, B., 1981. Deep-sea record of Cenozoic explosive volcanism in the North Atlantic. In: $S$. Self and R.S.J. Sparks (Editors), Tephra Studies. Kluwer, Dordrecht, pp. 289-316.

Spielhagen, R.F., 1991. Die Eisdrift in der Framstra $\beta$ e während der letzten 200,000 Jahre. Geomar Rep., 4: 1-133.

Stein, R., Grobe, H., Hubberten, H., Marienfeld, P. and Nam, S., 1993. Latest Pleistocene to Holocene changes in glaciomarine sedimentation in Scoresby Sund and along the adjacent East Greenland Continental Margin: Preliminary results. Geo-Mar. Lett., 13: 9-16.

Swift, J.H., 1986. The Arctic waters. In: B.G. Hurdle (Editor), The Nordic Seas. Springer, New York, pp. 129-153.

Thiede, J. and Hempel, G., 1991. Die Expedition ARKTISVII/1 mit FS "Polarstern" 1990. Polar Res., 80, 137 pp.

Vogelsang, E., 1990. Paläo-Ozeanographie des Europäischen Nordmeeres an Hand stabiler Kohlenstoff- und Sauerstoffisotope. Ber. Sonderforschungsbereich 313, Univ. Kiel, 23: 1-136.

Weinelt, M.S., Sarnthein, M., Vogelsang, E. and Erlenkeuser, H., 1991. Early decay of the Barents Shelf Ice Sheet-spread of stable isotope signals across the eastern Norwegian Sea. Nor. Geol. Tidsskr., 71: 137-140. 